\title{
Open-Source Software Application for Hydrogeological Delineation of Potential Groundwater Recharge Zones in the Singida Semi-Arid, Fractured Aquifer, Central Tanzania
}

\author{
Kassim Ramadhani Mussa ${ }^{1,2, * \mathbb{C}}$, Ibrahimu Chikira Mjemah ${ }^{2}$ and Revocatus Lazaro Machunda ${ }^{1}$ \\ 1 School of Materials, Energy, Water and Environmental Sciences, The Nelson Mandela African Institution of \\ Science and Technology, Arusha P.O. Box 447, Tanzania; revocatus.machunda@nm-aist.ac.tz \\ 2 Department of Geography and Environmental Studies, Sokoine University of Agriculture, \\ Morogoro P.O. Box 3038, Tanzania; chikira@sua.ac.tz \\ * Correspondence: kassimr@sua.ac.tz; Tel.: +255784312968
}

Received: 25 March 2020; Accepted: 12 May 2020; Published: 17 May 2020

\begin{abstract}
This study attempted to delineate and map potential groundwater recharge zones of the Singida, semi-arid, fractured crystalline basement aquifer using open source remote sensing and GIS software. Various thematic maps such as lithology/hydrogeology, soil, land-cover/use, slope, lineament density, drainage density and rainfall distribution were integrated in QGIS software. Vector input layers were rasterized and resampled using QGIS wrap projection function to make sure that the grid cells are of the same size. Reclassification using SAGA and GRASS reclass algorithms in QGIS was carried out to realign the factor classes in a consistent scale, and reclassification to a scale of 1 to 5 was carried out to harmonize the results. The study identified a number of potential areas for groundwater recharge, groundwater exploration, groundwater development and potential areas for artificial groundwater recharge. Potential groundwater recharge zones for the Singida semi-arid fractured aquifer are restricted to areas with high lineament density, cultivated areas, grassland and flat to gentle slopes. The potential of groundwater recharge is also observed in areas with low drainage density. The delineated zones provide a good understanding of the potential recharge zones, which are a starting point for recharge zone protection. This blended approach can be utilized for carrying out suitability analysis using the weighted overlay analysis approach. Areas designated good and very good are recommended for artificial recharging structures as an alternative technique for enhancing groundwater recharge through rainwater harvesting. This will help to augment groundwater storage in this semi-arid environment.
\end{abstract}

Keywords: potential groundwater recharge zones; semi-arid; fractured aquifer; weighted overlay analysis; open source software

\section{Introduction}

Groundwater plays a key role as an integral part of national water management strategies in many countries in the world. It is an important resource for food security, human health, ecosystems, economic and social prosperity of humankind. It is the largest available source of fresh water lying beneath the ground [1,2]. In dry areas of the world, groundwater is a key component of sustainable water management plans and strategies, because water resources are very scarce in those areas [3]. However, due to overexploitation for various uses, groundwater is declining steadily at a rate of approximately $545 \mathrm{~km}^{3}$ per year [4-6] in both humid and dry areas. Nonetheless, there are inadequate details regarding how much of the overexploited amount of groundwater is contributed to by regional, 
sub-regional or local flow systems. Therefore, decision and policymakers require adequate and correct information on the location of recharge areas, the amount of annual recharge, exploitation and the interconnectedness of groundwater flow systems for better management of groundwater resources.

In dry regions with high permeability terrains, regional groundwater flow makes up to $60 \%$ of the watershed budget $[7,8]$. On the contrary, regions with humid climates and low permeability terrains have less than $10 \%$ of the watershed budget coming from regional groundwater flow. Albeit, the questions about where exactly recharge occurs and which combination of hydrogeological and topographic factors control the rate of groundwater recharge remain inadequately addressed, both in dry and humid areas. In that regard, therefore, policy and technical actions to enhance groundwater recharge and protection of recharge zones have not been effective due to existing knowledge and information gaps. Determining groundwater recharge zones and locations is thus at the epicenter of the efforts to finding holistic solutions for water scarcity, groundwater resources management and governance for sustainable development.

Singida municipality and its peripheral suburbs entirely depend on groundwater for livestock production, crop irrigation, industrial and domestic uses for the largest part of the year. The rapidly increasing demand for urban water supply, expansion of groundwater uses for irrigation, livestock and water provision for dispersed urban communities exert an unprecedented pressure on the Singida semi-arid, fractured basement aquifer. Therefore, groundwater in the study area is such a valuable resource for socio-economic prosperity and development. In that regard, groundwater monitoring and protection is not an option but a crucial part of day-to-day activities of researchers, practitioners and policymakers. Delineation of potential groundwater recharge zones is thus imperative for fostering informed decision-making for water resource development and management [9].

In the recent past, there has been some scientific effort on the use of isotopes to correlate signatures and thus deduce the recharge locations, groundwater provenance and infer recharge sources for different aquifers $[10,11]$. Delineation of groundwater provenance in coastal aquifers of Tanzania using isotopic methods has also been carried out recently [12]. It was revealed that stable isotopes can be useful where groundwater provenance of a certain aquifer of interest is inadequately known [11,12]. Despite that usefulness isotopic methods give feeble details on spatial locations and areal extent of recharge zones, including inadequate details of the exact boundaries of recharge zones [12]. In addition to that, stable isotopes can trace groundwater provenance but cannot divulge the intensity of recharge which is likely to occur at a particular geographical location [12]. This has possibly been one of the factors leading to flawed decisions such as eviction of communities purportedly encroaching recharge areas. In addition to all these scientific drawbacks, to date, spatial delineation of recharge zones using remote sensing and GIS techniques is missing in the area, and in all other aquifers in Tanzania. Therefore, these few highlights give a glimpse of existing scientific and knowledge gaps which this study sought to address.

Elsewhere outside Tanzania, remote sensing and GIS techniques have been used to integrate various geological, hydrogeological, topographical and meteorological data to delineate potential groundwater recharge zones in the past [13-21]. In those previous studies, remote sensing and GIS techniques have proven useful for water resources assessment and monitoring. Appreciably, remote sensing and GIS techniques are capable of providing both, spatial and temporal trends of changes in recharge zones as a result of anthropogenic disturbances and interferences. This is because modern remote sensing and GIS technologies have good synoptic coverages, improved spatial resolution and also have good capabilities for multi-spectral and multi-temporal analyses.

While decision makers and practitioners are taking a keen interest on ensuring groundwater sustainability in the dry, arid and semi-arid areas, recharge mechanisms of most aquifers remain inadequately understood, including potential recharge areas of most aquifers. Moreover, the knowledge of the extent and controlling factors of groundwater recharge in most aquifers is inept, and very area-specific. As a result, trees have been planted in areas purportedly deemed recharge zones, 
and people have been evicted in areas they have been occupying, some legally due to claims that they are encroaching on recharge areas of some aquifers.

Owing to the aforementioned knowledge and scientific gaps, more comprehensive information is required to understand the ability, status and characteristics of various recharge zones in any basin, including the Singida, semi-arid, fractured basement aquifer in the Internal drainage basin in central Tanzania. Further to that, developing maps of potential groundwater recharge zones is critical for land use and groundwater resources planning, development and governance in the Singida, semi-arid, fractured basement aquifer. Demarcation of recharge zones and locations in the study area can as well serve as suitable areas for groundwater replenishment through artificial recharge. This is because natural (rainfall-based) recharge can no longer sustain the required supplies due to the ever-increasing water demand and diminishing recharge due to climate change and variability. Delineation of groundwater recharge zones is also imperative for safeguarding groundwater resources and community welfare especially in this era where groundwater constitutes an important source for various purposes.

This study therefore sought to provide information and knowledge for enhancing protection of the Singida semi-arid, fractured basement aquifer using open source remote sensing and GIS methods. The knowledge and information can be used to complement geochemical and isotopic studies in the study area and elsewhere in Tanzania and the world at large.

\section{Materials and Methods}

\subsection{Description of the Study Area}

The study area is located within the Internal Drainage Basin (IDB), which is described by rivers draining into a group of inland water bodies that are located around the north-central part of the country. The IDB is mainly made up of the system of troughs and faults running southward from lake Natron at the border with Kenya to central Tanzania in the Bahi depression in Dodoma region, and varies in width from 30 to $90 \mathrm{~km}$. The study area (Singida semi-arid fractured basement aquifer) is characterized by a network of ephemeral streams which only contain water during the rainy season, but they are otherwise dry in the largest part of the year. Further to that, the study area has two important wellfields, the Irao and Mwankoko wellfields which are the epicenter of water supply in Singida municipality and its peripheral suburbs (Figure 1). In addition, the study area is characterized by overlapping lineaments, which mainly characterize the geology of the area as it will be discussed in the following subsections. 


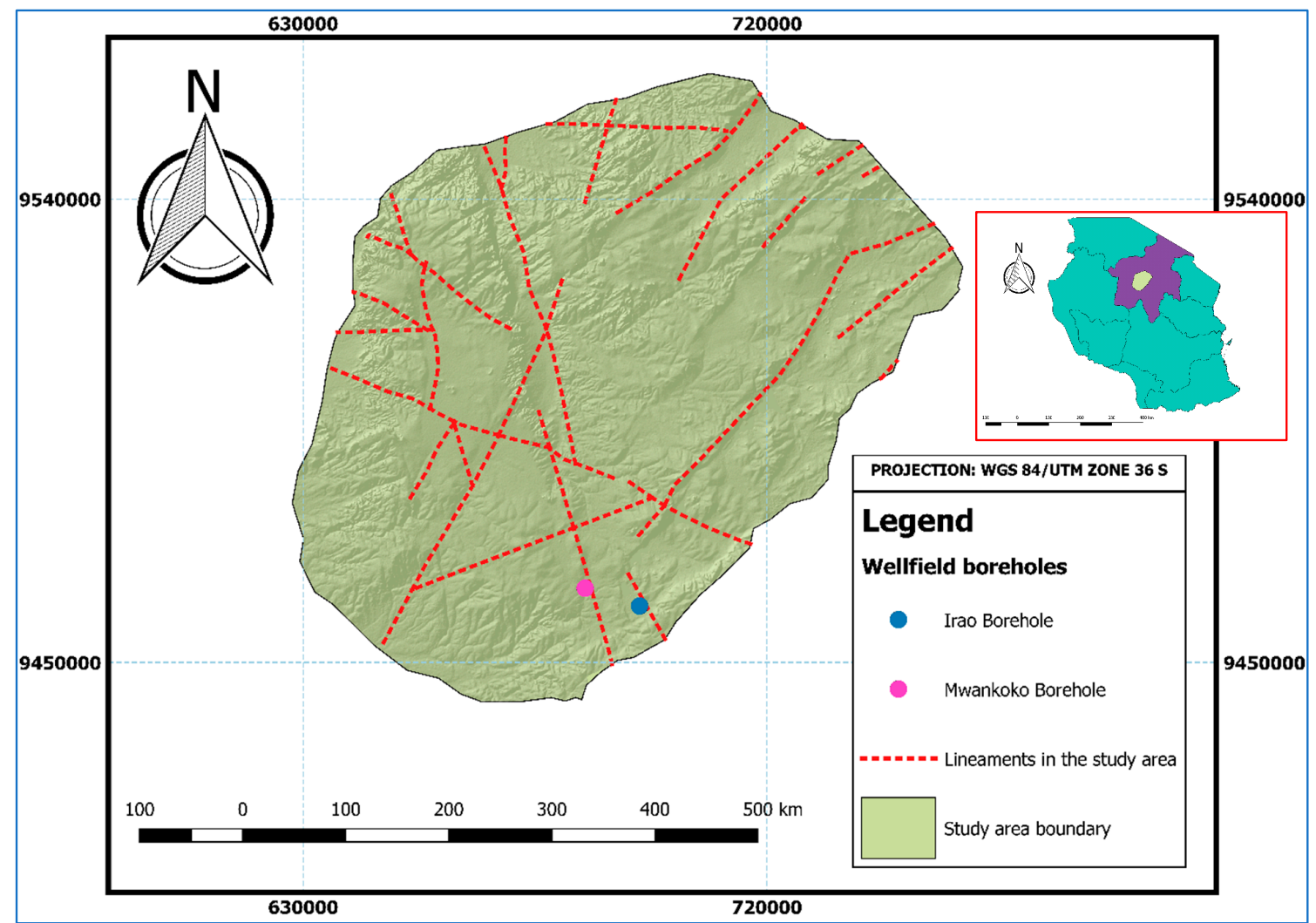

Figure 1. Maps showing the position of the study area relative to the internal drainage basin and the country (WGS 84/UTM Zone 36S: EPSG: 32736).

\subsection{Climate of the Study Area}

The study area receives average rainfall ranging from $600 \mathrm{~mm}$ to $800 \mathrm{~mm}$ per year, and it experiences a unimodal rainfall season, beginning in November until May (Figure 2). The annual evapotranspiration can be as high as $1400 \mathrm{~mm}$ per year. Although there are humid months, generally the area is typically semi-arid, with an average aridity index of 0.49 , with some months going to hyper-arid conditions as shown in Figure 3, Tables 1 and 2. This is due to a complete absence of rainfall in some months, but having very high evapotranspiration rates, usually above $100 \mathrm{~mm} / \mathrm{month}$ throughout the year (Table 1, Figure 2). Day temperatures range between 25 to $30^{\circ} \mathrm{C}$ while night temperatures may go down to $12{ }^{\circ} \mathrm{C}$. The months of July, August and September are the driest of all (Figure 2). Generally, the area falls within the driest areas of the IDB, and hence the main source of water is groundwater from deep and shallow wells. 


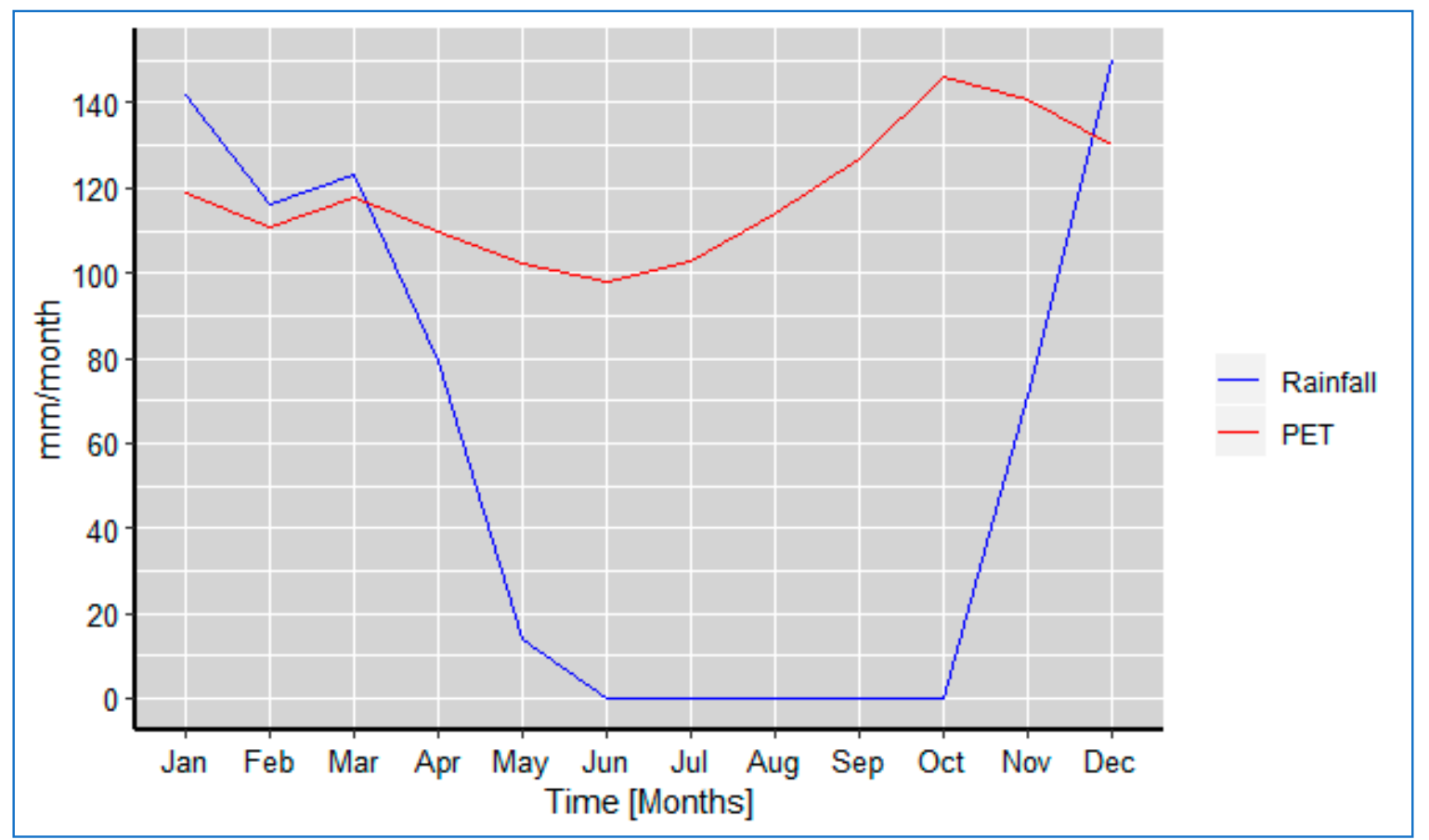

Figure 2. Mean monthly rainfall and potential evapotranspiration in the study area.

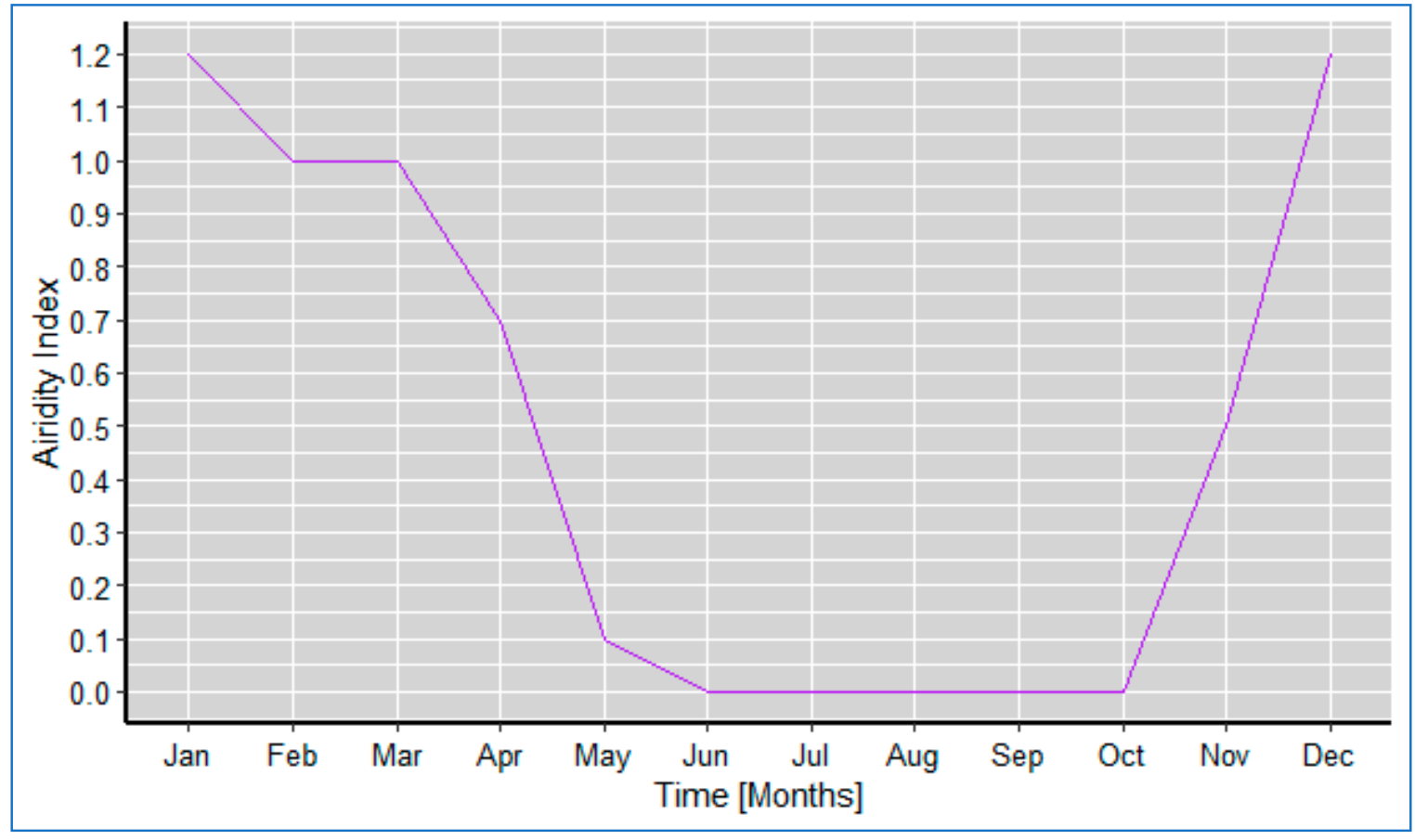

Figure 3. Mean monthly Aridity Index in the study area. 
Table 1. Mean monthly climatic parameters of the Singida fractured crystalline basement aquifer.

\begin{tabular}{cccccccc}
\hline Month & $\begin{array}{c}\text { Precipitation } \\
(\mathbf{m m} / \mathbf{m o n t h )}\end{array}$ & $\begin{array}{c}\text { PET } \\
(\mathbf{m m} / \mathbf{m o n t h})\end{array}$ & $\begin{array}{c}\text { Aridity } \\
\text { Index (AI) }\end{array}$ & Aridity Status & $\begin{array}{c}\mathbf{T}_{\min } \\
\left({ }^{\circ} \mathbf{C}\right)\end{array}$ & $\begin{array}{c}\mathbf{T}_{\max } \\
\left({ }^{\circ} \mathbf{C}\right)\end{array}$ & $\begin{array}{c}\mathbf{T}_{\text {mean }} \\
\left({ }^{\circ} \mathbf{C}\right)\end{array}$ \\
\hline January & 142 & 119 & 1.2 & Humid & 17 & 28 & 21 \\
February & 116 & 111 & 1.0 & Humid & 17 & 28 & 21 \\
March & 123 & 118 & 1.0 & Humid & 17 & 27 & 21 \\
April & 79 & 110 & 0.7 & Humid/Sub-humid & 17 & 27 & 21 \\
May & 14 & 102 & 0.1 & Arid & 15 & 26 & 20 \\
June & 0 & 98 & 0.0 & Hyper-arid & 13 & 25 & 19 \\
July & 0 & 103 & 0.0 & Hyper-arid & 12 & 25 & 18 \\
August & 0 & 114 & 0.0 & Hyper-arid & 13 & 26 & 18 \\
September & 1 & 127 & 0.0 & Hyper-arid & 14 & 28 & 21 \\
October & 9 & 146 & 0.1 & Arid & 16 & 29 & 22 \\
November & 61 & 141 & 0.4 & Semi-arid & 17 & 29 & 22 \\
December & 150 & 130 & 1.2 & Humid & 17 & 29 & 22 \\
& $\mathbf{6 9 5}$ & $\mathbf{1 4 1 9}$ & $\mathbf{0 . 4 9}$ & & SEMI-ARID & \\
\hline
\end{tabular}

Table 2. Aridity Indices.

\begin{tabular}{ccc}
\hline \multirow{2}{*}{ Status } & $\begin{array}{c}\text { P/PET } \\
\text { (Penman-Monteith Method) }\end{array}$ & $\begin{array}{c}\text { P/PET } \\
\text { (Thornthwaite Method) }\end{array}$ \\
\cline { 2 - 3 } & Aridity Index & Aridity Index \\
\hline Hyper-Arid & $<0.03$ & $<0.05$ \\
Arid & $0.03-0.2$ & $0.05-0.2$ \\
Semi-Arid & $0.21-0.5$ & $0.21-0.5$ \\
Sub-humid & $0.51-0.75$ & $0.51-0.65$ \\
Humid & $>0.75$ & 0.75 \\
\hline
\end{tabular}

\subsection{Geology}

Geologically, the study area is found within five main geological units, which are classified into 6 units, which include some small lakes denoted as Lk (Figure 4). There are also lineaments extending north-south, north-east, south-west with some branching to south-east and north-west. The main geological units are plutonic rocks consisting of granite and granodiorite, foliated, gneissose or migmatitic. Some massive porphiyroblastic, including intimately related regional migmatite. Lithologically, they are of two types, (i) those with topographic rough texture (gs) and strongly weathered granite with smooth topographic texture (gs-b). There is a Nyanzan system $(Z)$ which occupies the central part of the study area, extending east-west, and north east is made up of banded ironstone; metavolcanics; chlorite schist; and pseudo-porphyry (Figure 4). Patches of Cenozoic sediments $(\mathrm{N})$, which are mostly alkaline volcanics in the north, north-eastern central western parts of the study area have been observed. These are characterized by olivine basalt, alkali basalt, phonolite, trachyte, nephelinenite and pyroclastics and (NI), made up of lacustrine, sand, silt, limestone and tuff, which can be observed in the southern, western and north-western parts of the study area (see Figure 4). 


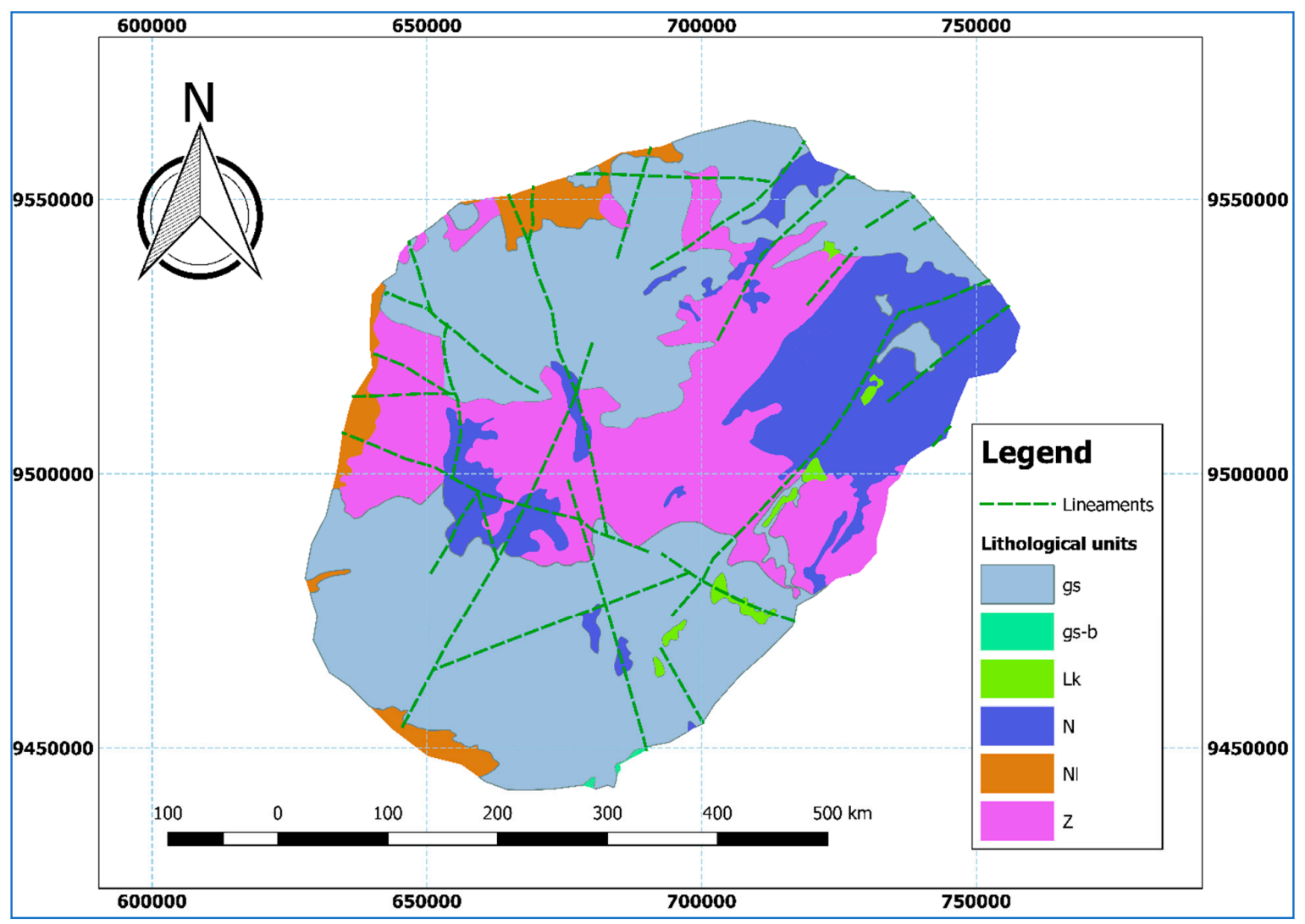

Figure 4. The geology of the study area and the lineament system distribution (WGS 84/UTM Zone 36S: EPSG: 32736).

\subsection{Input Thematic Maps}

\subsubsection{Lithology/Hydrogeology}

The study area is hugely made of four main hydrogeological classes which are important for determining groundwater recharge potential (Figure 5). These are the Precambrian craton (B-L/M1), which are the shields in which the basement rock has cropped out at the surface and platforms. The basement is overlaid by sediments and sedimentary rock. The Precambrian craton in the study area is composed of ancient crystalline basement rock, which in some areas are covered by younger sedimentary rocks [22-24]. The Kimberlites (B-L/M2), which are rock fragments (xenoliths) carried up from the mantle by magmas containing peridotite and delivered to the surface as inclusions in subvolcanic pipes called kimberlites $[22,24,25]$. These inclusions have densities consistent with craton composition and are composed of mantle material residual from high degrees of partial melt. Peridotite is strongly influenced by the inclusion of moisture. Generally, there are two main hydrogeological features which determine the potential of the area for groundwater recharge, the Precambrian craton (B-L/M1) and the tertiary to quaternary unconsolidated materials (U-L/H). The latter (U-L/H) have very high potential while the former is very poor at influencing groundwater recharge through primary porosity and permeability (Figure 5). There is also a small patch of tertiary to quaternary volcanic rocks (I-L/M) on the eastern side of the study area. The potential of tertiary to quaternary volcanic rocks in influencing groundwater recharge is considerably good. 


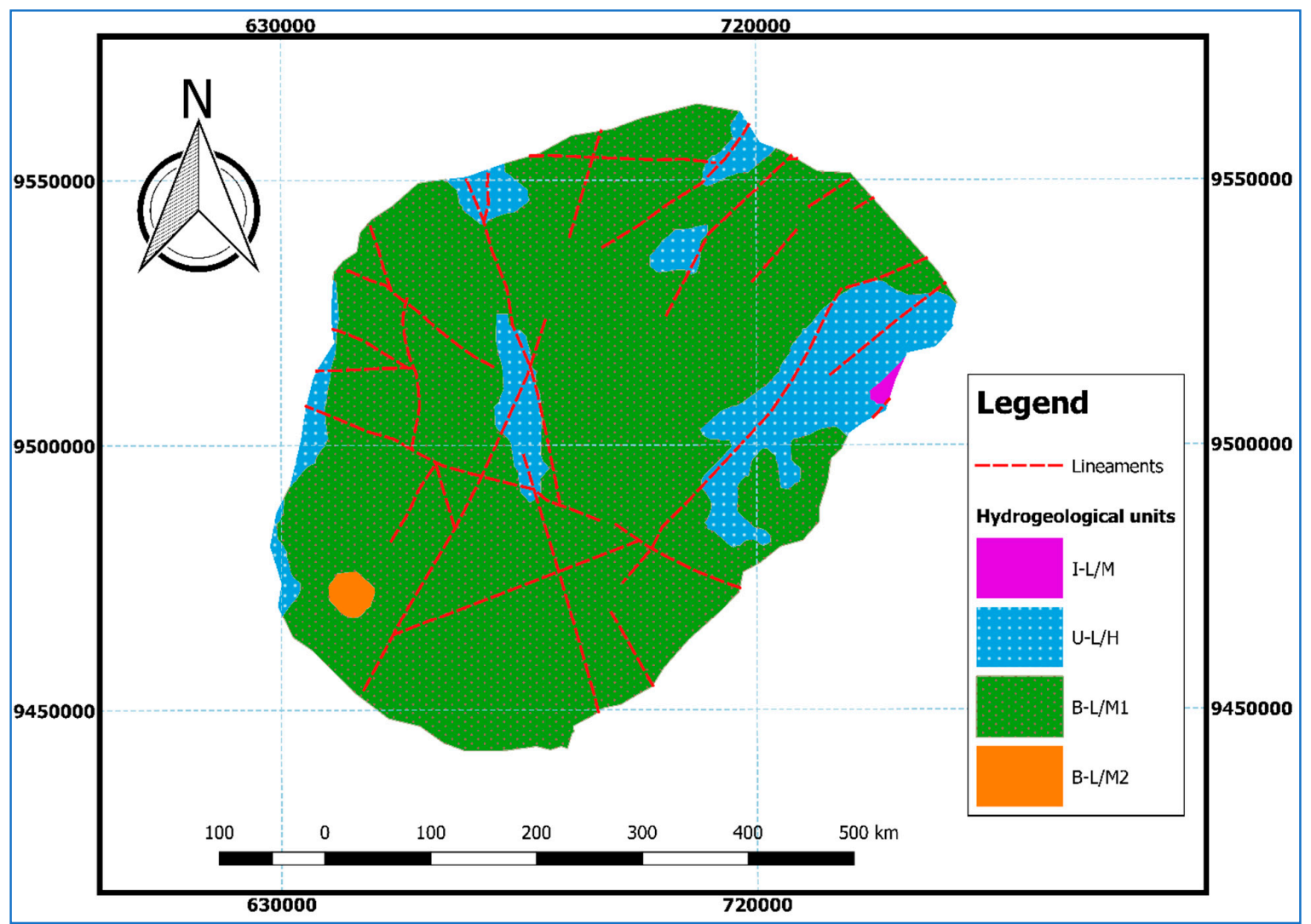

Figure 5. Map showing the hydrogeology of the study area (WGS 84/UTM Zone 36S: EPSG: 32736).

\subsubsection{Lineaments and Lineament Density}

Lineaments form what is called secondary porosity in crystalline basement aquifers. Thus, groundwater occurrence, flow and the recharge in the study area is mainly by this type of porosity, and as shown in the Figure 6, the area is highly fractured. The open fractures are excellent features for artificial recharge too. Lineament density varies between 0 to $10 \mathrm{~km} / \mathrm{km}^{2}$ (see Figure 6).

The rule of thumb is, the higher the lineament density, the more likely is recharge to occur. Therefore, the lineament density of $0-0.6 \mathrm{~km} / \mathrm{km}^{2}$ is very poor in terms of groundwater recharge potential while the potential of $8-10 \mathrm{~km} / \mathrm{km}^{2}$ is very high. Lineament density is the result of the length of lineaments in a square kilometer area. It was established using Equation (1) as suggested by other researchers [21]:

$$
L_{d}=\frac{\sum_{i=1}^{n}\left(L_{i}\right)}{A}
$$

where, $L_{d}$ is lineament density $\left(\mathrm{km} / \mathrm{km}^{2}\right), L_{i}$ is the total length of all lineaments $(\mathrm{km})$ and $A$ is the area of the grid $\left(\mathrm{km}^{2}\right)$. 


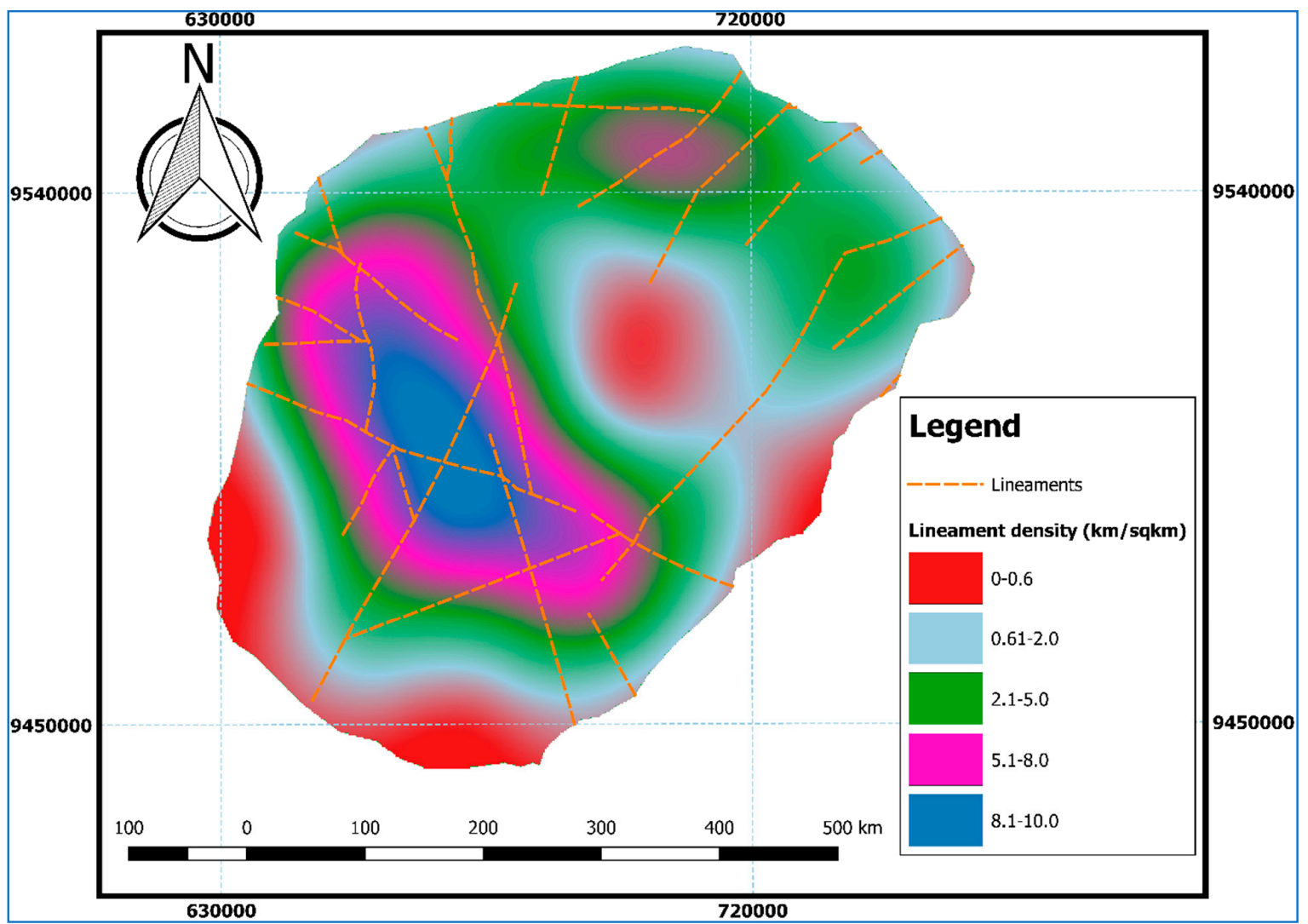

Figure 6. A map showing the lineament density with lineaments (WGS 84/UTM Zone 36S: EPSG: 32736).

\subsubsection{Drainage and Drainage Density}

Drainage density has been derived from the stream network of the study area (Figure 7). It gives an idea of how drained the study area is. It is also an indication of the likelihood of the occurrence of surface runoff as a result of more drainage channels. Drainage density was calculated using Equation (2) as follows:

$$
D_{d}=\frac{\sum_{i=1}^{n}\left(D_{i}\right)}{A}
$$

where, $D_{d}$ is drainage density $\left(\mathrm{km} / \mathrm{km}^{2}\right), D_{i}$ is the total length of streams $(\mathrm{km})$ and A is an area of a $\operatorname{grid}\left(\mathrm{km}^{2}\right)$. 


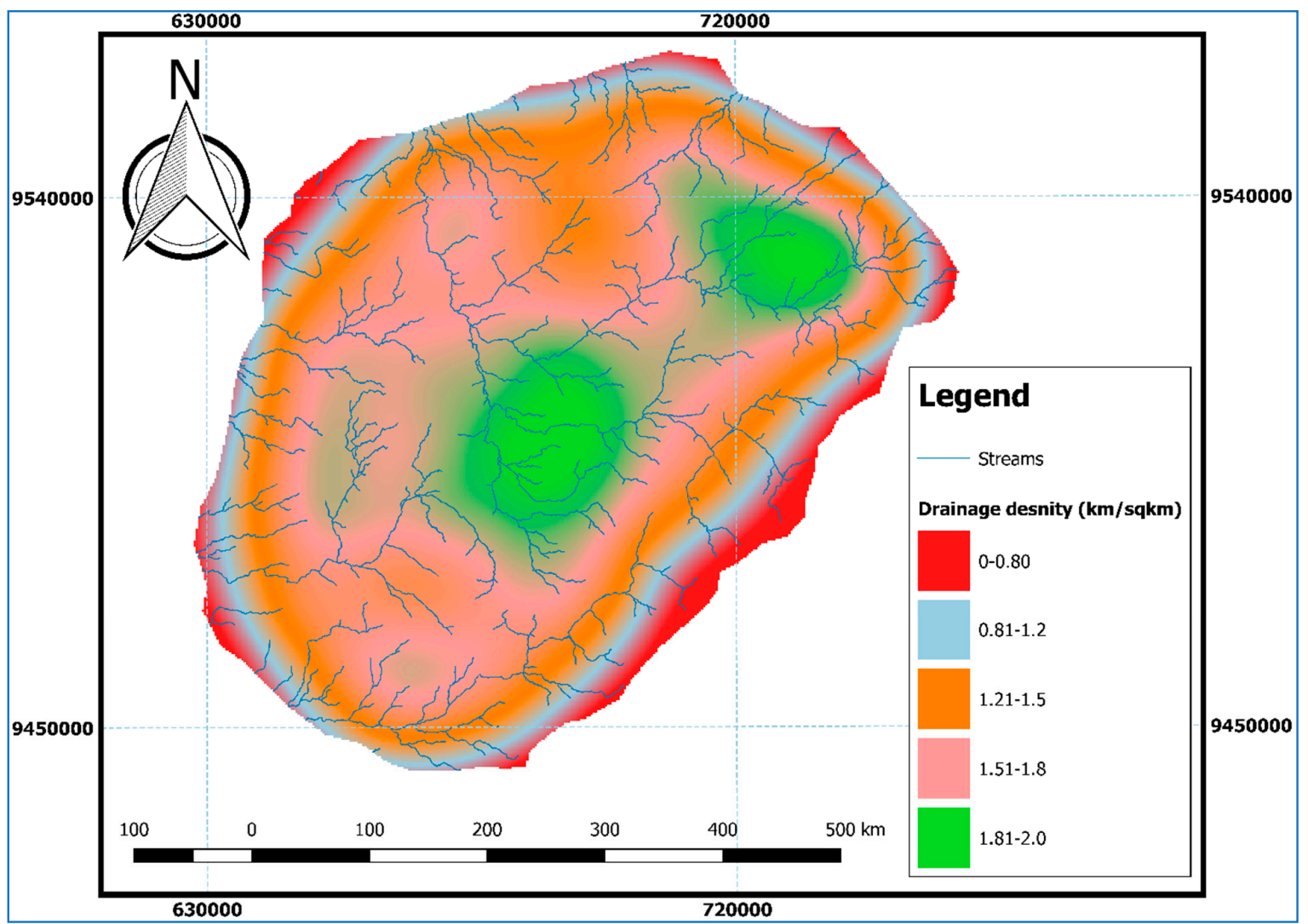

Figure 7. A map showing the drainage density of the study area (WGS 84/UTM Zone 36S: EPSG: 32736).

\subsubsection{Land Use/Cover}

A 2018 Landsat 8 image, captured using Operational Land Imager (OLI) sensor of 17th September 2018 was downloaded from the U.S. Geological Survey's Earth Explorer website from Path 169, Row 063 with less than $10 \%$ cloud cover in the study site. The image was preprocessed by firstly converting the satellite image bands from Digital Number (DN) to surface reflectance. The conversion of raster bands to surface reflectance included performing image-based atmospheric correction using the Dark Object Subtraction (DOS1) method. This was done to improve the classification results. The image preprocessing was followed by creation of the Regions of Interest (ROIs), which are the model training samples aimed at defining the land cover classes in the study area which are to be used for land cover/use model simulation as well as collecting spectral signatures for image processing.

Thereafter, classification of the image using the semi-automatic classification plugin (SCP) of the QGIS (version 2.14.2) software was performed using the maximum likelihood algorithm. All the data were exported into QGIS and reprojected to the Universal Transverse Mercator Projection WGS 84/UTM Zone 36S, (EPSG: 32736). In terms of land uses/covers, the study area has 8 distinct classes namely, water bodies, wetlands, built-up area, forest, grassland, bushes, woodland and cultivated area. Cultivated, grassland and bushland are the most dominant land covers while built-up area, wetland and water bodies (mainly lakes) occupy a small portion of the study area (Figure 8). 


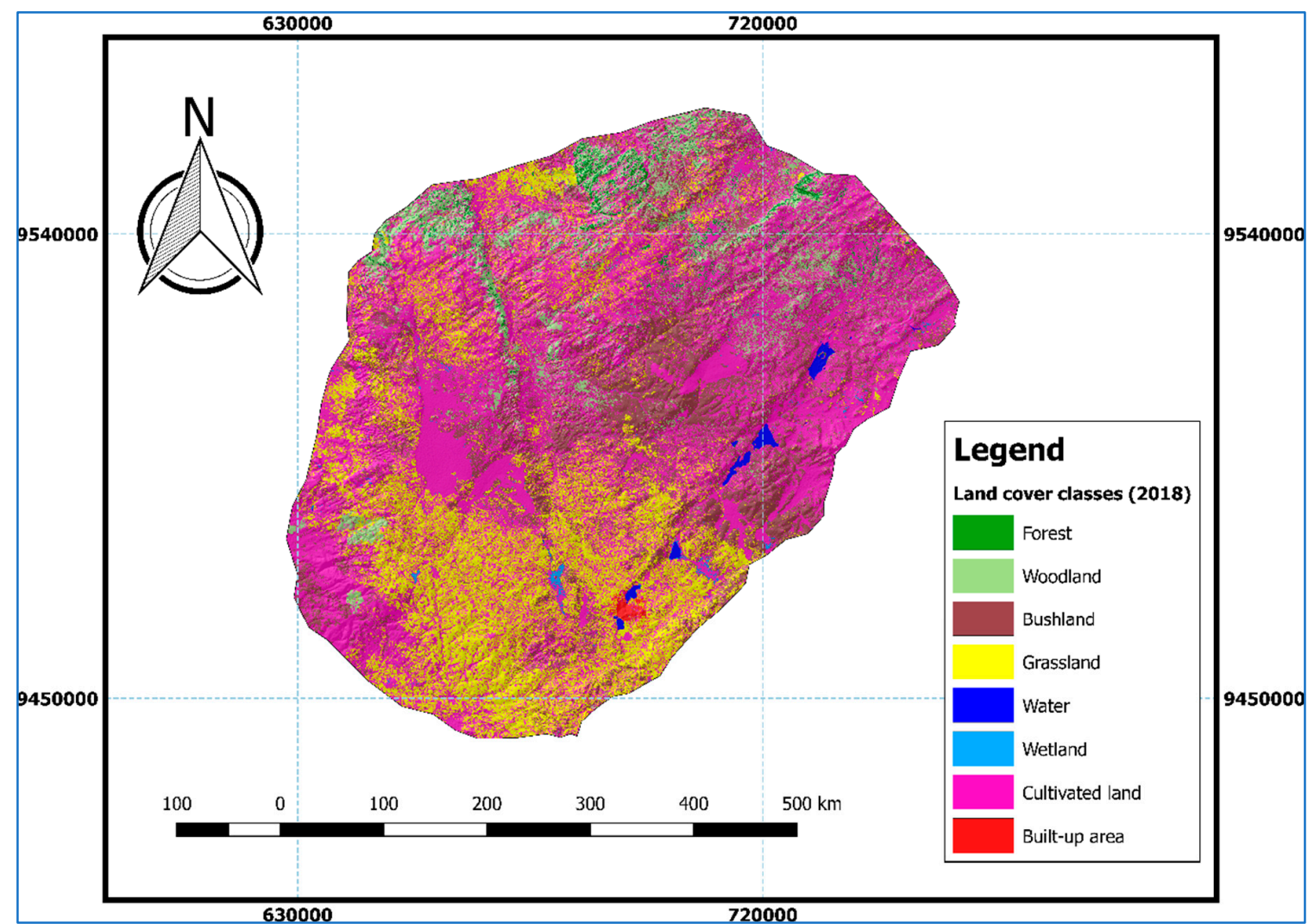

Figure 8. Land use/cover map of the study area (WGS 84/UTM Zone 36S: EPSG: 32736).

\subsubsection{Rainfall Distribution}

The study area is divided into three distinctive rainfall zones (Figure 9). The first zone that covers the largest part of the study area receives a maximum of $700 \mathrm{~mm}$ per year. The second zone which is a small patch in the south and north (red colored) receives a maximum of $600 \mathrm{~mm}$ per year, and is the driest zone in the study area. The third zone, which is relatively small, located in the north western, extending towards the central part of the study area receives a maximum of $800 \mathrm{~mm}$ per year. With respect to rainfall, the rule of thumb is, the more the rainfall received, the higher the likelihood of groundwater recharge provided that other favorable conditions exist. 


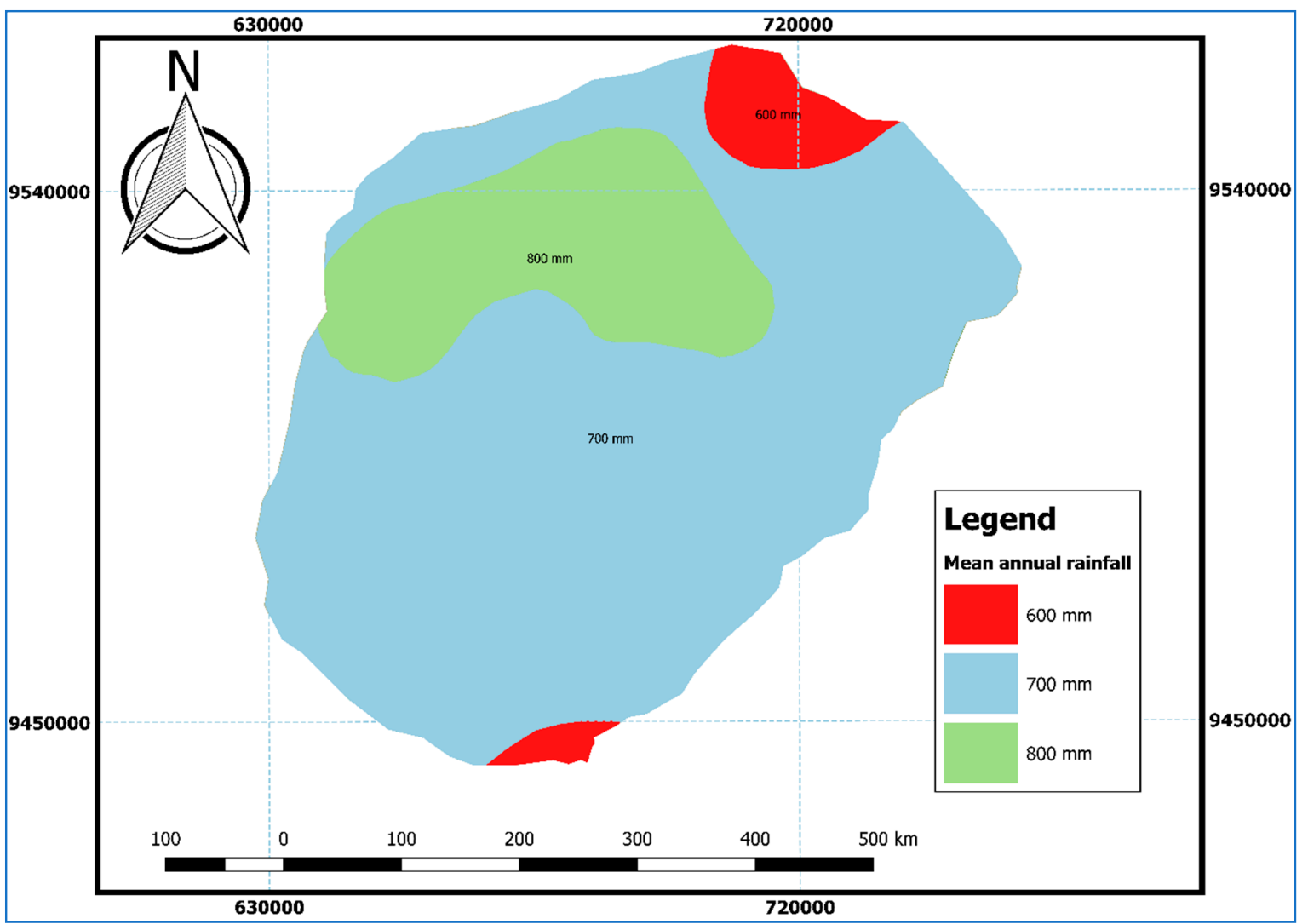

Figure 9. Rainfall distribution in the study area (WGS 84/UTM Zone 36S: EPSG: 32736).

\subsubsection{Soil}

The study area is covered by six soil types. The first type is ferric Acrisols (Af3-1/2a), which is made up of sedimentary materials. This type is found in landscapes that have an undulating topography. Acrisols are defined by the presence of a subsurface layer of accumulated kaolinitic clays. This covers the biggest part of the study area (see Figure 10). There are also calcic cambisols (Bk29-2ab), which are characterized by an increasing clay content with depth. Moreover, the study area is also cover by eutric fluvisols (Je52-2/3a) in the north, north western and western parts of the study area. This is regarded as the most suitable soil for water infiltration, and potential groundwater recharge thereof. These are formed from unconsolidated water-borne materials, and are of recent alluvial deposits with good properties for water infiltration. Lithosols (I-L-R-bc), consisting of a thin soil made up of mainly partially weathered rock fragments also make up the soil types in the study area. They are shallow soils consisting of imperfectly weathered rock fragments. The potential for groundwater recharge is fairly low. Dystric nitosols (Nd38-2bc) and eutric nitosols (Ne38-2ab) which are deep, red, well-drained soils with a clay content of more than $30 \%$ and a blocky structure are also found in the study area. In addition to being inherently the most fertile soils of the tropical soils due to their high nutrient content, their characteristic depth gives them a permeable structure and thus a very good groundwater recharge potential. 


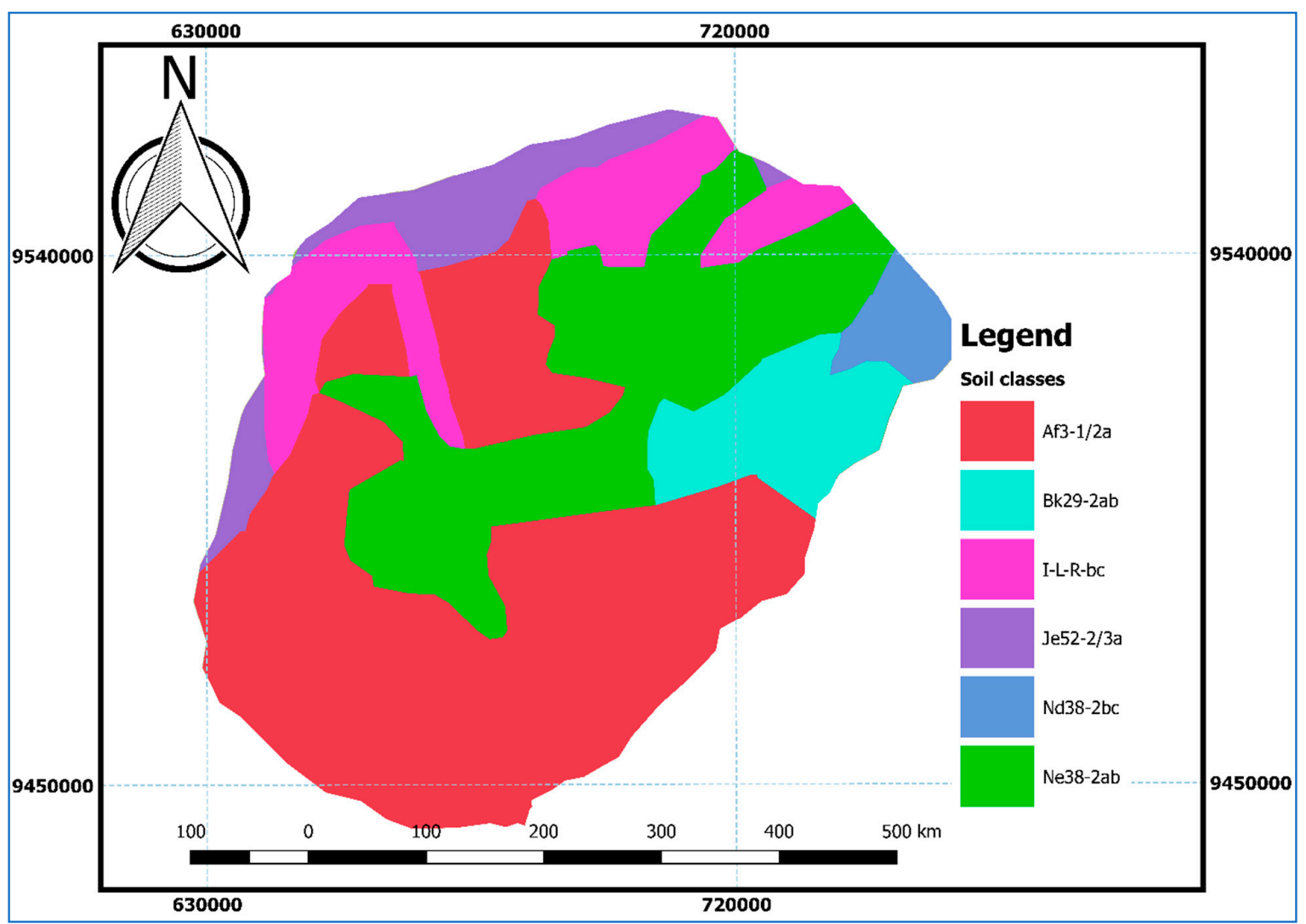

Figure 10. Soil classes in the study area (WGS 84/UTM Zone 36S: EPSG: 32736).

\subsubsection{Slope}

The study area is divided into 3 slope classes. These are flat to gentle slope area, moderate slope and steep slope as shown in Figure 11. Generally, the largest portion of the study area is flat to moderately sloppy, which favors groundwater recharge. 


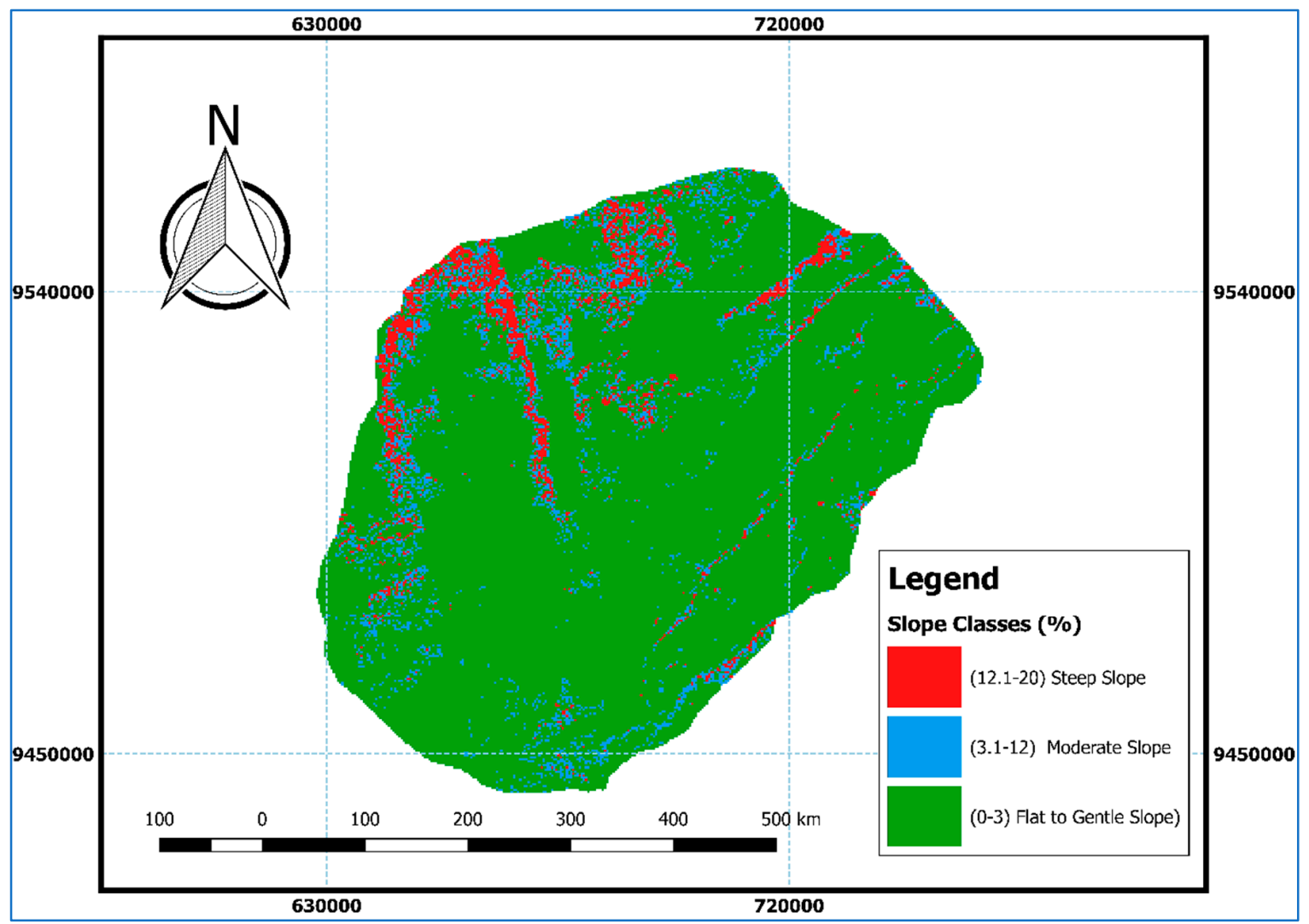

Figure 11. Slope classes in the study area (WGS 84/UTM Zone 36S: EPSG: 32736).

\subsection{Determining the Factor Relations and Percentage Influence of the Thematic Layers}

The percentage influence score was derived from the interrelationship among all the factors (Table 3). A score of 1 and 0.5 were assigned for major influence and minor influence, respectively for all the parameters as shown in Table 3. Therefore, the total weight of each factor results from the sum of the measure of influence for each parameter. The higher the weight of the parameter the higher the influence on groundwater recharge potential and low influence connotes low groundwater recharge potential as discussed in previous studies [21].

Table 3. Percentage influence, factor scores and ranks of the main thematic layers.

\begin{tabular}{|c|c|c|c|c|}
\hline Thematic Layer & Major Influence ( $\left.\mathrm{I}_{\text {major }}\right)$ & $\begin{array}{l}\text { Minor Influence } \\
\left(I_{\text {minor }}\right)\end{array}$ & $\begin{array}{c}\text { Factor Score } \\
(\mathrm{FS})= \\
\left(\mathrm{I}_{\text {major }}+\mathrm{I}_{\text {minor }}\right)\end{array}$ & $\begin{array}{c}\begin{array}{c}\text { Factor Influence } \\
\text { (FI) }\end{array} \\
\frac{(F S)}{\sum(F S)} \times 100\end{array}$ \\
\hline Lineament density & $\begin{array}{l}\text { Hydrogeology, soil, drainage } \\
\text { density, land use/cover, slope }\end{array}$ & & 5.0 & 21 \\
\hline Hydrogeology/Lithology & Drainage, soil, lineaments, & $\begin{array}{l}\text { Slope, drainage } \\
\text { density }\end{array}$ & 4.0 & 17 \\
\hline Lan use/cover & $\begin{array}{l}\text { Drainage density, Soil, } \\
\text { hydrogeology }\end{array}$ & Lineament density, & 3.5 & 15 \\
\hline Soil & $\begin{array}{l}\text { Drainage density, land } \\
\text { use/cover, hydrogeology, }\end{array}$ & Lineament density & 3.5 & 15 \\
\hline Rainfall & $\begin{array}{l}\text { Drainage density, land } \\
\text { use/cover, hydrogeology }\end{array}$ & & 3.0 & 13 \\
\hline Slope & $\begin{array}{l}\text { Drainage density, } \\
\text { hydrogeology }\end{array}$ & & 2.5 & 11 \\
\hline Drainage density & Land use/cover, hydrogeology & & $\begin{array}{c}2.0 \\
\sum(F S)=23.5\end{array}$ & $\begin{array}{c}8 \\
100\end{array}$ \\
\hline
\end{tabular}


The proposed factor scores and factor influence for all the parameters were calculated by using Equation (3) and Equation (4) while class influence of each factor was calculated using Equation (5) and Equation (6):

$$
\begin{gathered}
F S=\left(I_{\text {major }}+I_{\text {minor }}\right) \\
\boldsymbol{F I}=\frac{F S}{\sum(F S)} \times 100
\end{gathered}
$$

The ranking was given for each individual parameter of each thematic map and weights were assigned according to the multi influencing factor of that particular feature on the hydrogeological environment of the study area. The summary of inputs, materials, methods, approaches and processes is shown in a schematic diagram (Figure 12) and Table 4.

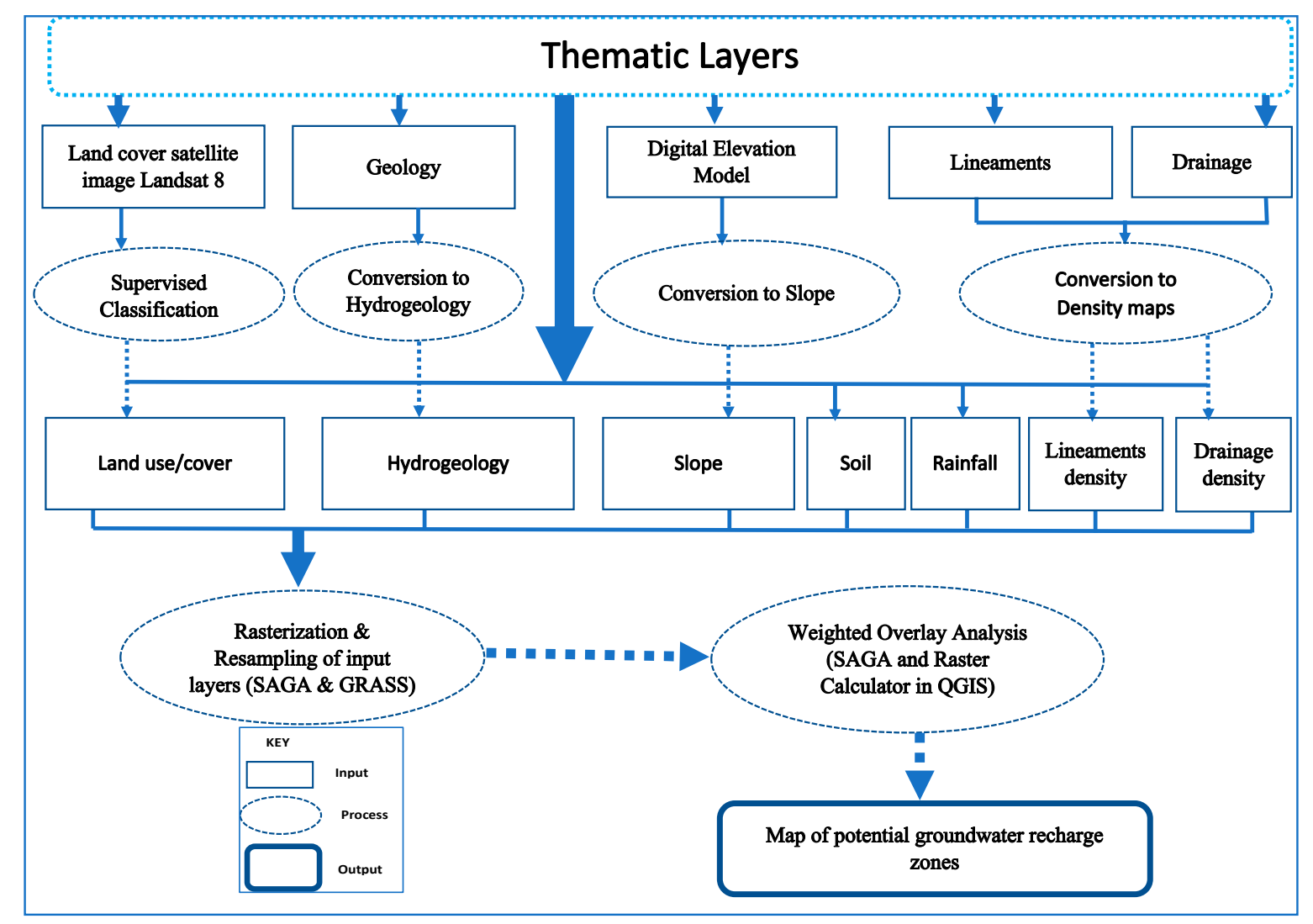

Figure 12. Schematic diagram of the requisite processes, methods and input data for delineating groundwater potential zones.

Previous studies [17] reported that groundwater level is chiefly related to geomorphology, geology, lineaments, slope and rainfall, with land use and soil being the minor relationships. It was further reported that geology is related to lineaments, groundwater level and geomorphology but less related to slope, land use/cover and soil [17]. It was additionally argued by other previous researchers [20] that land use/cover and drainage are also less related to geology. It was opined further that lineaments, geology and groundwater level are the major relationships while land use and slope are the minor relationships [20]. Soil is related to land use/cover as a major relationship but les related to rainfall, geology, groundwater level and geomorphology. According to the findings of other studies [17], slope has groundwater level as a major relation while lineaments, rainfall, land use/cover and geology are the minor relationships. Arguably, slope is mainly related to rainfall and drainage and the other factors are minor relationships [20]. The relationship among hydrogeological factors has also been reported in other studies $[9,19]$ and they are not different from what has been reported by similar studies $[17,20]$. 
Table 4. Factor classes, class rank and factor weightage.

\begin{tabular}{|c|c|c|c|c|}
\hline $\begin{array}{c}\text { Factor } \\
\text { Parameter }\end{array}$ & Class & $\begin{array}{c}\text { Class Rank } \\
\text { (Equation (3) and } \\
\text { Equation (4)) }\end{array}$ & $\begin{array}{c}\text { Reclassified } \\
\text { Ranks } \\
\text { (Scale 1-5) }\end{array}$ & $\begin{array}{c}\text { Factor } \\
\text { Weightage } \\
(\%)\end{array}$ \\
\hline \multirow{4}{*}{$\begin{array}{l}\text { Lineament } \\
\text { density }\end{array}$} & $8.1-10.0$ & 21 & 5 & \multirow{4}{*}{21} \\
\hline & $5.1-8.0$ & 16 & 4 & \\
\hline & $2.1-5.0$ & 11 & 3 & \\
\hline & $0.6-2.0$ & 6 & 1 & \\
\hline \multirow{4}{*}{ Hydrogeology } & $\begin{array}{l}\text { Tertiary quaternary } \\
\text { unconsolidated }\end{array}$ & 17 & 5 & \multirow{4}{*}{17} \\
\hline & $\begin{array}{c}\text { Tertiary quaternary volcanic } \\
\text { aquifer }\end{array}$ & 13 & 4 & \\
\hline & Kimberlites & 9 & 3 & \\
\hline & Precambrian Craton & 5 & 1 & \\
\hline \multirow{6}{*}{ Land cover } & Grassland & 15 & 5 & \multirow{6}{*}{15} \\
\hline & Cultivated land & 12.5 & 4 & \\
\hline & Water body & 10 & 3 & \\
\hline & Forest & 7.5 & 3 & \\
\hline & Bare land & 5.0 & 2 & \\
\hline & Built-up area & 2.5 & 1 & \\
\hline \multirow{6}{*}{ Soil } & Je52-2/3a (Eutric Fluvisols) & 15 & 5 & \multirow{6}{*}{15} \\
\hline & Af3-1/2a (Ferric Acrisols) & 12.5 & 4 & \\
\hline & Nd38-2bc (Dystric Nitosols) & 10 & 3 & \\
\hline & Ne38-2ab (Eutric Nitosols) & 7.5 & 3 & \\
\hline & Bk29-2ab (Calcic Cambisols) & 5.0 & 2 & \\
\hline & I-L-R-bc (Lithosols) & 2.5 & 1 & \\
\hline \multirow{3}{*}{ Rainfall } & $800 \mathrm{~mm}$ & 13 & 5 & \multirow{3}{*}{13} \\
\hline & $700 \mathrm{~mm}$ & 9 & 4 & \\
\hline & $600 \mathrm{~mm}$ & 5 & 2 & \\
\hline \multirow{3}{*}{ Slope } & $0-3.0$ & 11 & 5 & \multirow{3}{*}{11} \\
\hline & $3.1-12.0$ & 7 & 3 & \\
\hline & $12.1-20$ & 3 & 1 & \\
\hline \multirow{5}{*}{$\begin{array}{c}\text { Drainage } \\
\text { density }\end{array}$} & $0-0.80$ & 8 & 5 & \multirow{5}{*}{8} \\
\hline & $0.81-1.2$ & 6.4 & 4 & \\
\hline & $1.21-1.5$ & 4.8 & 3 & \\
\hline & $1.51-1.8$ & 3.2 & 2 & \\
\hline & $1.81-2.0$ & 1.6 & 1 & \\
\hline
\end{tabular}

According to previous researchers $[7,8]$, and taking the study area as a reference point, the relationship between slope and groundwater levels and depth to water table is subtle. The values of major and minor factor relations are adopted and modified as reported in other studies $[9,17-20]$ as 1 and 0.5 , respectively. Given the geological setting of the study area, and following a thorough review of previous works of the same nature, key factors to be considered for determining potential recharge areas in the study area are hydrogeology/lithology, land use/cover, lineament density, drainage density, slope, soil, mean annual rainfall distribution and slope. These can reveal how effective rainfall-based recharge happens as well as how effective the areas are for artificial groundwater recharge. Those are the thematic maps which have been utilized in the Weighted Overlay Analysis to come up with an aggregate map of potential recharge areas.

According to previous studies [20], given a total number of classes $(N)$ of a thematic factor, the influence of the first class $\left(C_{1}\right)$ to groundwater recharge is the same as the factor influence $(F I)$ (Equation (5)):

$$
C I_{1}=F I
$$


The influence of the second class $\left(\mathrm{CI}_{2}\right)$ in a thematic factor is equal to the Influence of the first class $\left(C I_{1}\right)$ minus the ratio between the factor influence $(F I)$ and the total number of classes $(N)$ in that particular thematic factor (Equation (6)). Therefore, for calculating $C I$ for all classes with $n \geq 2$, Equation (6) applies:

$$
C I_{n}=C I_{n-1}-\frac{(F I)}{N}
$$

\subsection{Rasterization, Resampling and Reclassification}

Vector input layers were rasterized and resampled using QGIS wrap projection algorithm/function to resize the grid cells and reproject the input thematic layers. Thereafter, reclassification using GRASS reclass algorithms was carried out to put all the factor classes in a consistent scale. Reclassification to a scale of 1 to 5 was made to harmonize the results obtained through Equations (5) and (6). This was the final input which was then subjected to Weighted Overlay Analysis (WOA) as discussed in the next subsection.

\subsection{Weighted Overlay Analysis}

Weighted overlay analysis is a method of modeling suitability which aimed at creating a composite map by combining the geometry and attributes of all 7 input thematic layers as discussed by other researchers [15]. The logic behind weighted overlay analysis is to get a combined scenario map that represents the overall groundwater recharge potential possibility of a given area in the context of the chosen and weighted input parameters and their corresponding factor classes. Unlike the weighted overlay approach using the spatial analyst tool in ArcGIS software, the ordered weighted averaging (OWA) in QGIS software, which is the equivalent of the ArcGIS one is a somehow limited.

Therefore, weighted overlay analysis in this study was a two-pronged process. Thematic maps were added together in a weighted combination with their factor weightage as percentage (Table 4). This step involved multiplying each layer's weight by each cell's ranked value, and, as a result, a weighted cell value was produced. This was carried out using the algorithm in a SAGA GIS. Thereafter, the weighted cell values were totaled for each overlaying cell and then written to an output layer using raster calculator function in QGIS software. The raster calculator operation in QGIS superimposes multiple raster layers, representing different hydrogeological, topographic and hydroclimatic themes together with their resampled grid cells and their ranked classes. Thus, the two processes were used to integrate the thematic layers of soil, hydrogeology, lineament density, slope, land cover, rainfall distribution, drainage density of the study area to produce a final weighted overlay analysis output (see Figure 12). This step resulted into the groundwater potential recharge zone map.

The resulting map consisted of zones of groundwater potential which were put into a scale of very good (5), good (4), intermediate (3), poor (2) and very poor (1). This categorization of potential recharge zones in the study area was used to depict the potential of the study area with regard to groundwater recharge, both from rainfall as well as for artificial recharge techniques.

\section{Results}

\section{Groundwater recharge potential from each thematic factor and their respective classes}

The final map obtained from each thematic factor was regarded as a layer, each with its own weight and special characteristics with respect to contribution to the overall recharge potential for the study area. After various thematic map classes were assigned with different numerical values with respect to groundwater recharge potential, they were converted into a scale of $1-5$, and each class was categorized into very good to very poor just to depict the influence of each class to groundwater recharge potential (Figure 13). 


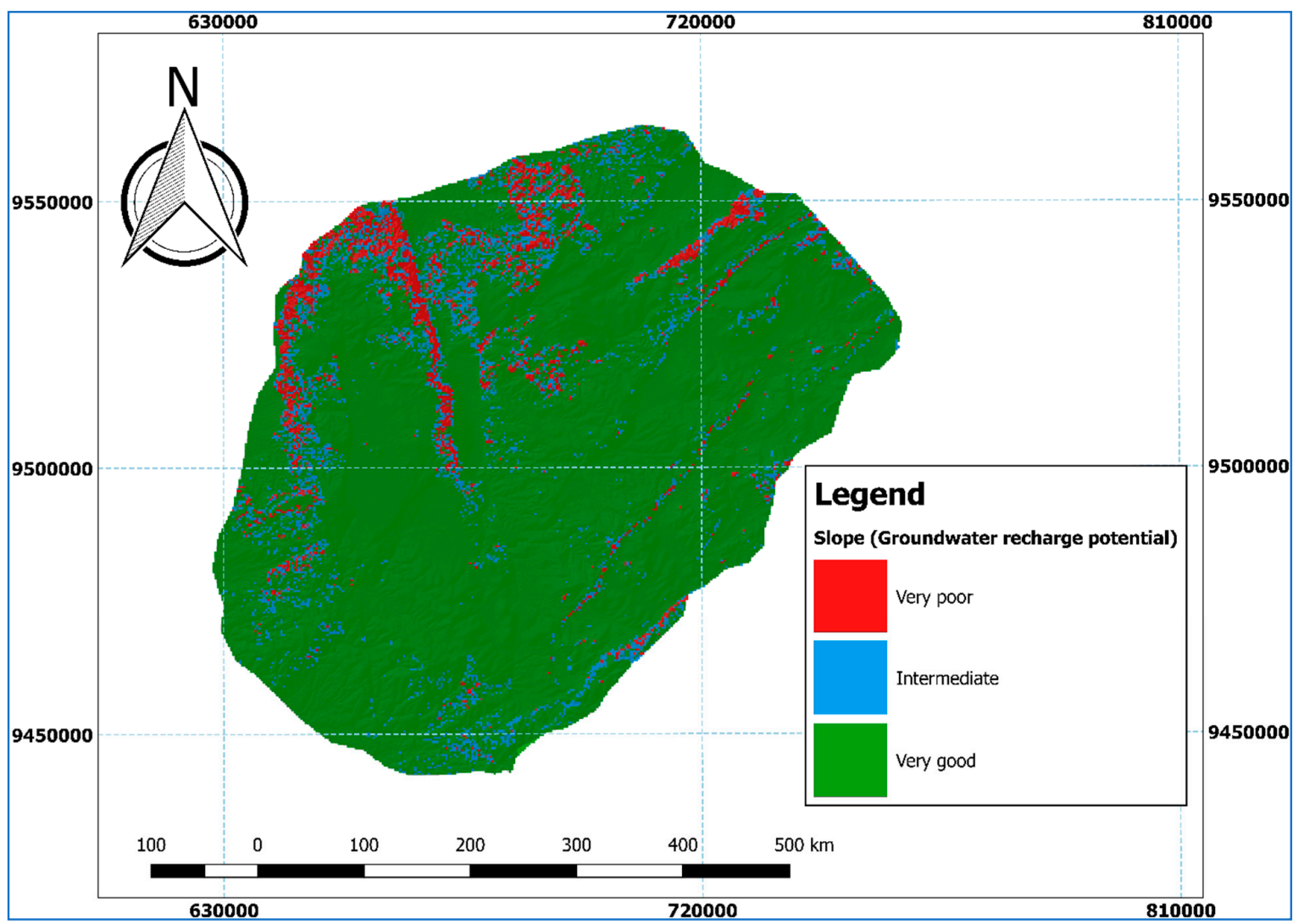

Figure 13. Groundwater recharge potential of slope classes (WGS 84/UTM Zone 36S: EPSG: 32736).

Just like the final output (groundwater recharge) map, the thematic factor classes have a varying effect on groundwater recharge potential. The hydrogeological delineation revealed that the study area is covered by three classes of groundwater recharge potential with respect to slope. Flat to gentle slope areas are the areas which are the most suitable for groundwater recharge while steep slopes are unfavorable for recharge. This is supported by previous researchers [26]. Albeit, the largest part of the study area is low-lying (Figure 13), and thus presents good conditions for water infiltration, and ultimately percolation to the aquifer. Arguably, water usually follows the slope and accumulates in areas with the lowest elevation regardless of lithological setting of that particular area [20]. Therefore, the lower the slope, the higher the potential for groundwater recharge and the higher the slope the lower the suitability of area as a recharge zone [27-32]. Steep slopes and rocky outcrops $(12.1-20 \%)$ presented bad attributes for groundwater recharge potential. This is further reiterated by previous researchers [21].

In another aspect, the distribution of water bearing geological units is one of the most important factors which play significant role in the distribution and occurrence of groundwater in any basin $[9,20,33]$. After a thorough lithological assessment, followed by a detailed hydrogeological analysis of the rock formations in the study area, the hydrogeological units in the study area were reduced into two with respect to their groundwater recharge potential (Figure 14). They were classified into very high (unconsolidated materials) to very poor (consolidated, cratonic and kimberlite hard rocks). The later have very poor primary porosity and thus permeability while unconsolidated materials are very good at allowing water passage through their well-connected pores. Reportedly, the storage capability of the rock formations depends on the type and porosity of the rock [24,34]. In the rock formation, the water moves from areas of recharge to areas of discharge under the influence of hydraulic gradients depending on the permeability and/or hydraulic conductivity of a rock formation [34]. 


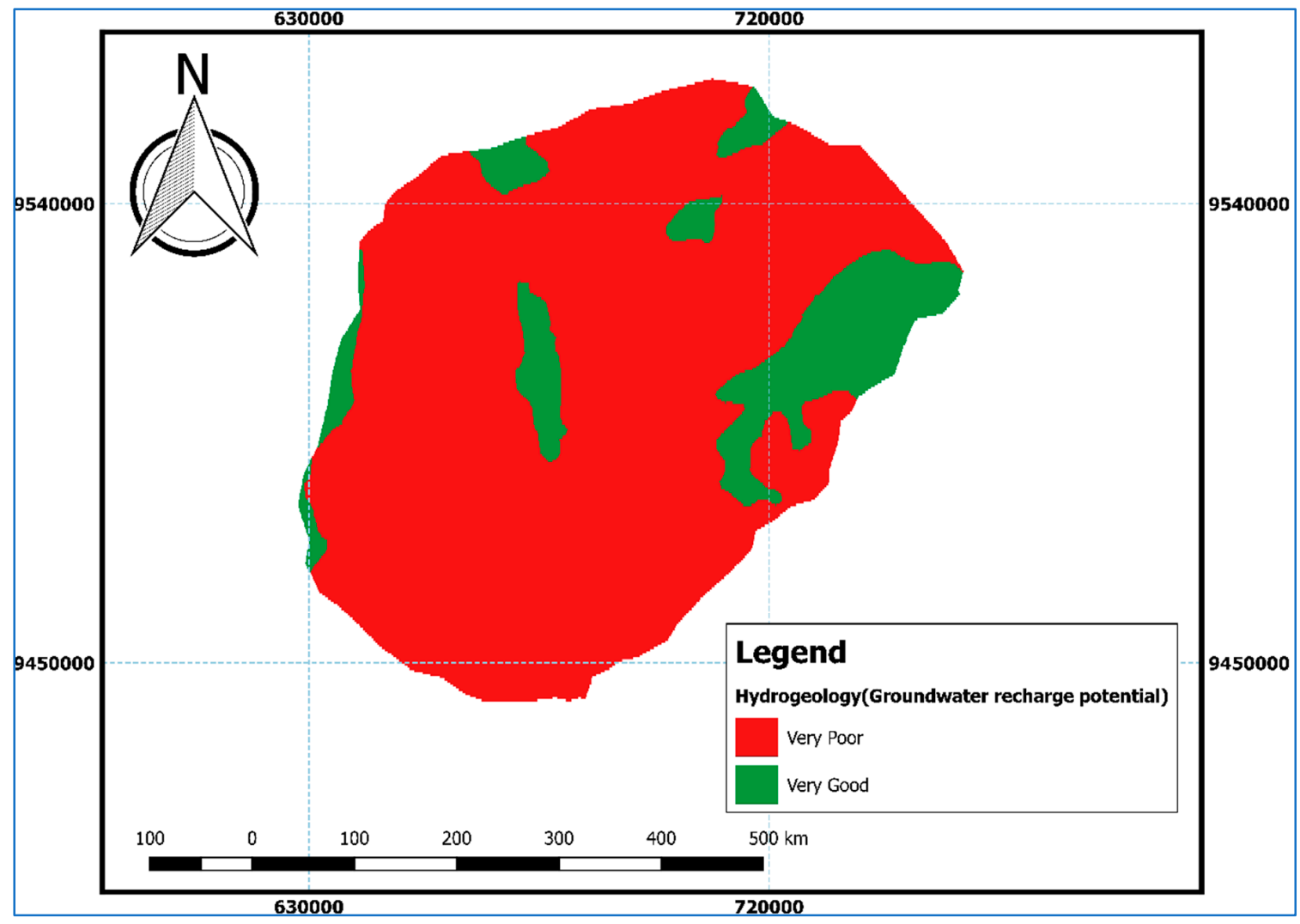

Figure 14. Groundwater recharge potential of hydrogeological units (WGS 84/UTM Zone 36S: EPSG: 32736).

The potential of groundwater recharge from the rainfall distribution follows an increasing trend. The higher the rainfall amount the higher the potential for groundwater recharge. Groundwater recharge is only possible when rainfall is higher than potential evapotranspiration (PET), after considering the ensuing runoff. This means that recharge is only possible when net rainfall (rainfall minus the runoff) is larger than the PET. Nevertheless, this does not ensure a spontaneous recharge since the amount of water that is left, after subtracting the PET from the net rainfall will first be held by the soil. At a certain point the amount of water held by the soil will exceed its maximum threshold called field capacity. The surplus of water after reaching the field capacity will recharge the groundwater reservoir. At this point, the potential evapotranspiration is lower than rainfall. Therefore, the more the rainfall received in an area, the higher the likelihood of overcoming potential evapotranspiration and thus surpassing the field capacity of the soil material, towards getting water surplus which usually percolates into the groundwater reservoir. Thus, the area which receives rainfall of $800 \mathrm{~mm}$ per year is more likely to influence groundwater recharge than the area receiving rainfall of $600 \mathrm{~mm}$ per year or less, given other geological factors are favorable (Figure 15). Rainfall has a huge bearing on the groundwater potential in arid and semi-arid areas [21]. This is because other sources of water are uncertain and where available are unevenly distributed.

Lineaments are well distributed in the central to western parts of the study area. Thus, areas with high lineament density are classified as very good potential recharge areas as opposed to areas with low lineament density (Figure 16). In consolidated geological structures and highly fractured areas, secondary porosity, which is derived from fractures and lineaments are the most important features for groundwater flow and recharge. Therefore, Figure 16 categorizes the study area into five groups (very good to very poor) with respect to potential for groundwater recharge. Reportedly, areas having high lineament density have very good potential of groundwater recharge [21]. This is well reflected in the findings of this study as shown in Figure 16. In this study the contribution of lineaments to groundwater recharge potential is very good given the geology and hydrogeology of the 
area. Lineament density is one of the most prominent influencing factors in consolidated and fractured crystalline basement aquifers where they act as secondary porosity through which recharge may occur and groundwater travels (Table 4, Figure 16).

With respect to drainage, the chance for water infiltration into the groundwater system is higher in areas where water is drained slower than in areas that have high drainage density. Therefore, areas with lower drainage density have high groundwater recharge potential since run-off is lower. The central parts of the study area are covered by areas with high drainage density (Figure 17). As reported by previous studies, higher drainage density implies higher run off and therefore little water will find its way through to the aquifer [35-37].

As far as soil is concerned, six groundwater recharge potential classes were obtained in the study area. They range from very good to very poor, with two intermediate classes as shown in Figure 18. Alluvial soil is potentially very good to good in influencing groundwater recharge while red and brown soils are good to moderate respectively. Black soil is moderate at influencing groundwater recharge as reported by other studies $[17,34]$. This knowledge has been applied in the ranking of soil classes with respect to groundwater recharge potential (See Table 4 and Figure 18). The ranking of the soil classes in this study considered soil texture and depth, the factors which have a major impact on groundwater recharge potentiality of an area [38-40].

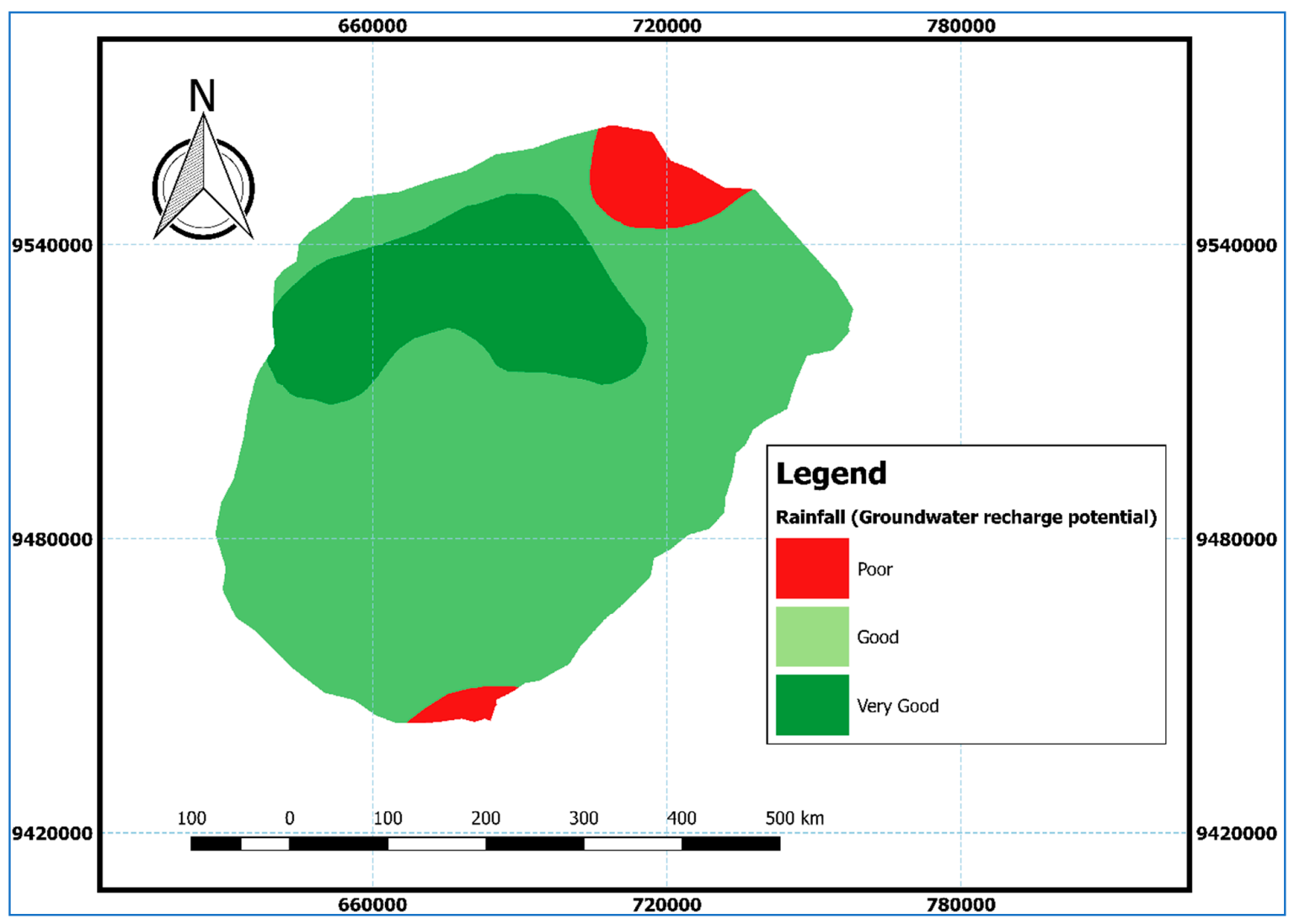

Figure 15. Groundwater recharge potential of rainfall distribution classes (WGS 84/UTM Zone 36S: EPSG: 32736). 


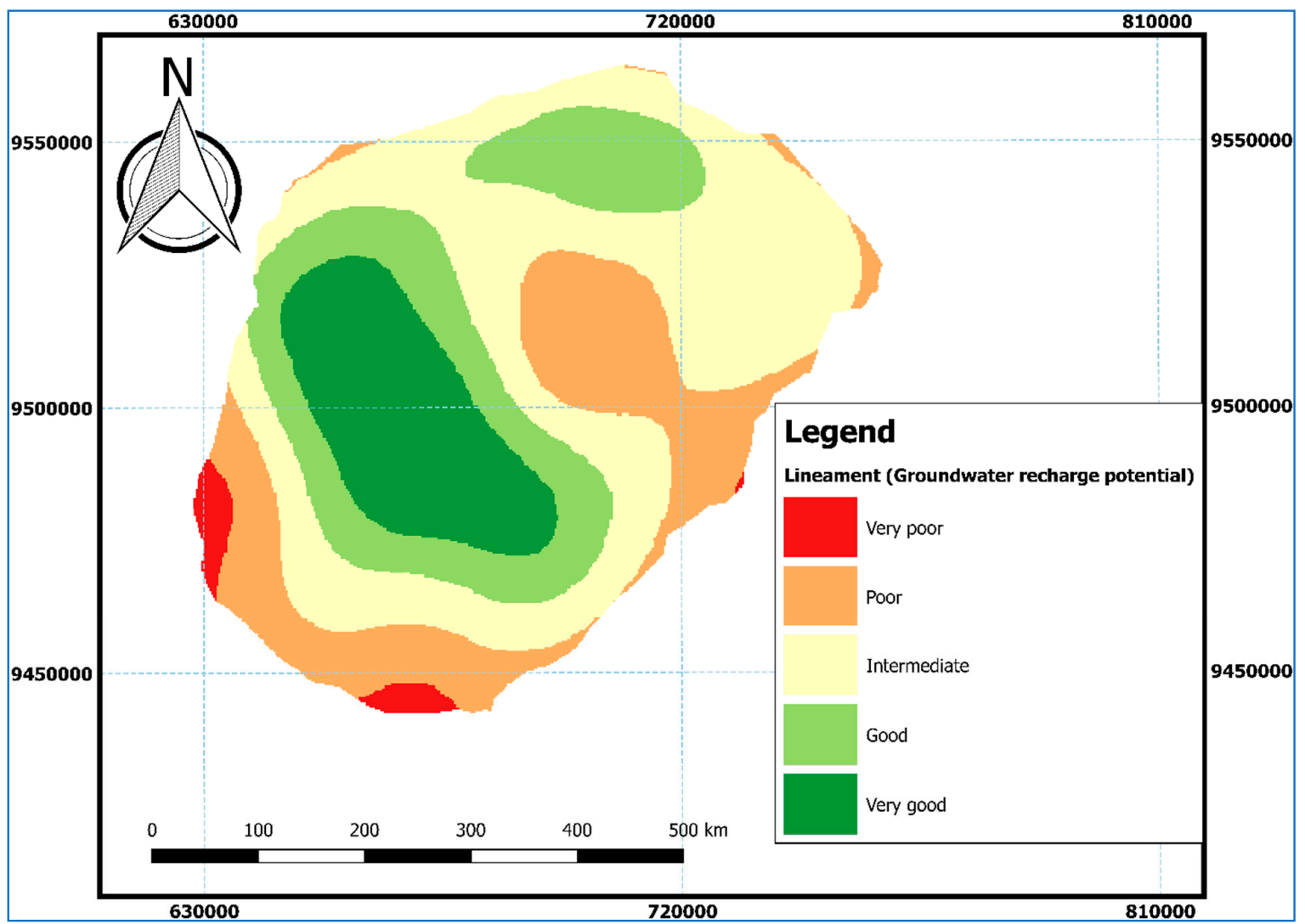

Figure 16. Groundwater recharge potential of lineament density classes (WGS 84/UTM Zone 36S: EPSG: 32736).

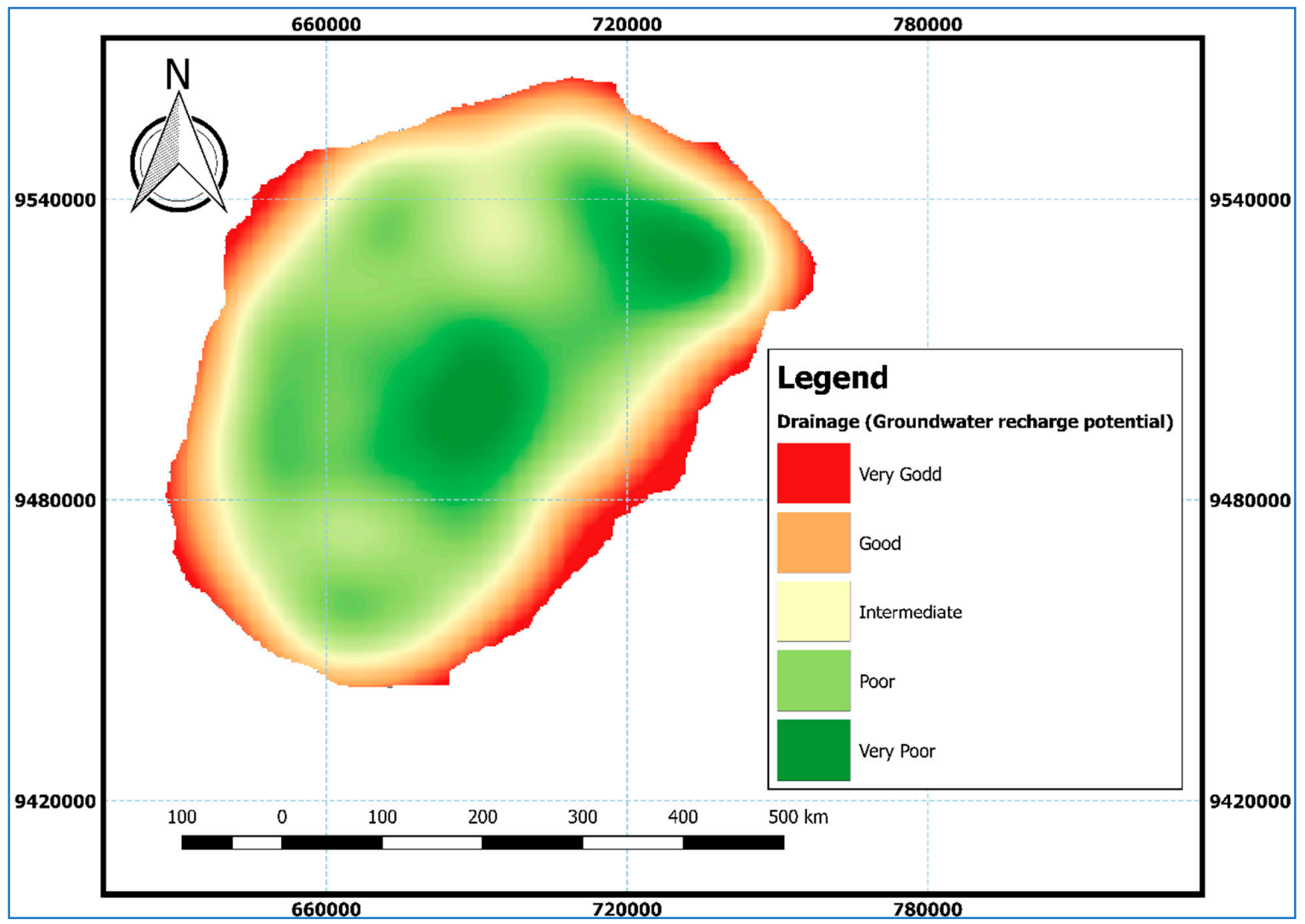

Figure 17. Groundwater recharge potential of drainage density classes (WGS 84/UTM Zone 36S: EPSG: 32736). 


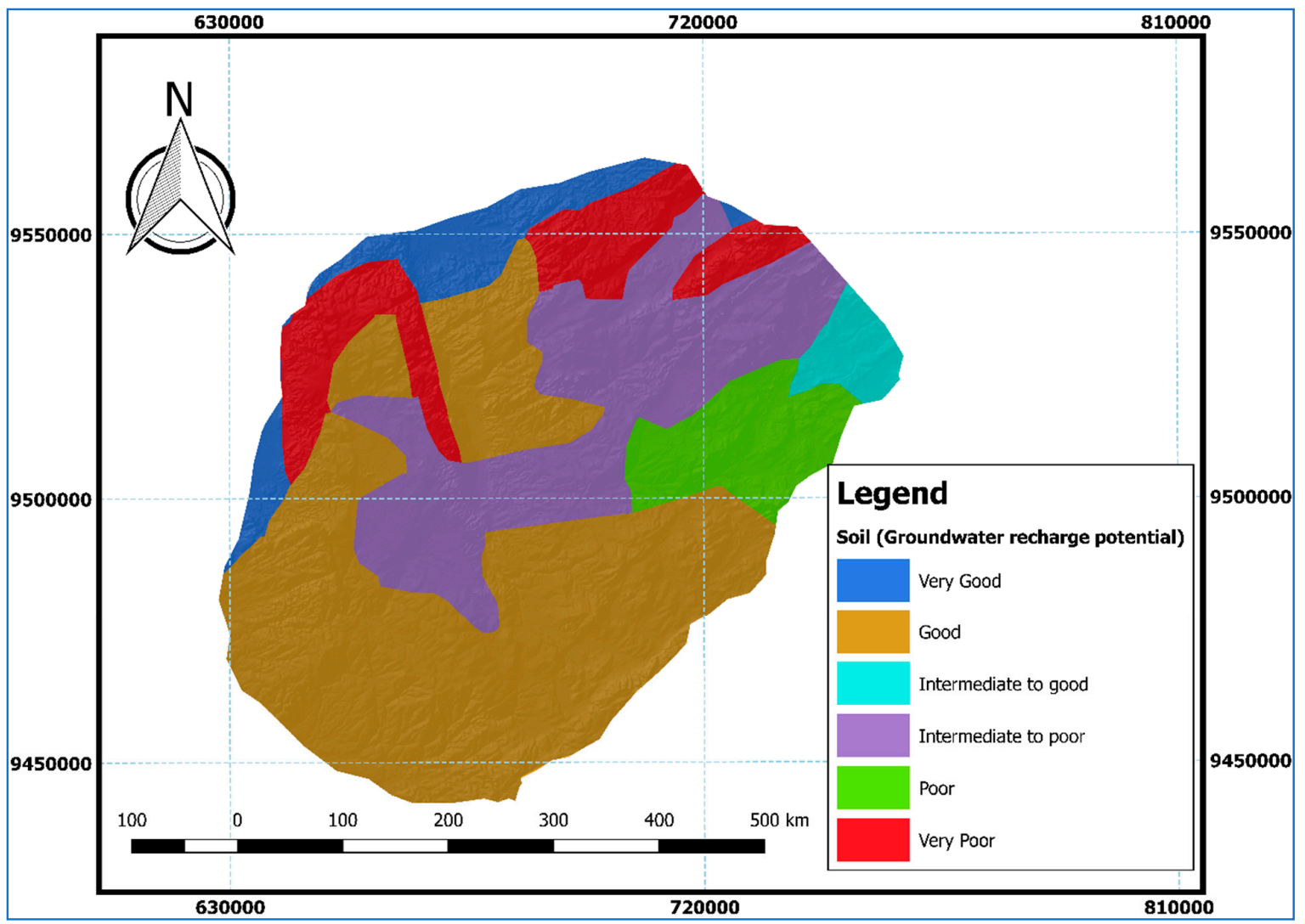

Figure 18. Groundwater recharge potential of soil classes (WGS 84/UTM Zone 36S: EPSG: 32736).

The classification of land use/cover classes with regard to groundwater recharge potential informs that areas that are highly built-up and paved are least suitable for groundwater recharge potential. This is because of more surface run-off ensuing from hard surfaces while agricultural and forest lands are good due to the availability of loose soil on the surface [21,40]. There is a vast grassland and bushes in the study area, and together with the cultivated land, they form good to very good recharge potential areas (Figure 19). While forests usually form suitable areas for groundwater recharge elsewhere as reported in other studies [21,40], in the study area, the potential of forest and woodland in influencing groundwater recharge has been reduced by the fact that they occur in rocky outcrops and highly slopping areas (see Figures 14 and 19). Therefore, combining the two factors reduces the potential of forested land on groundwater recharge in the study area. The aptness of agricultural lands and grasslands for groundwater recharge and the unsuitability of built-up areas have been reported in previous studies [40]. 


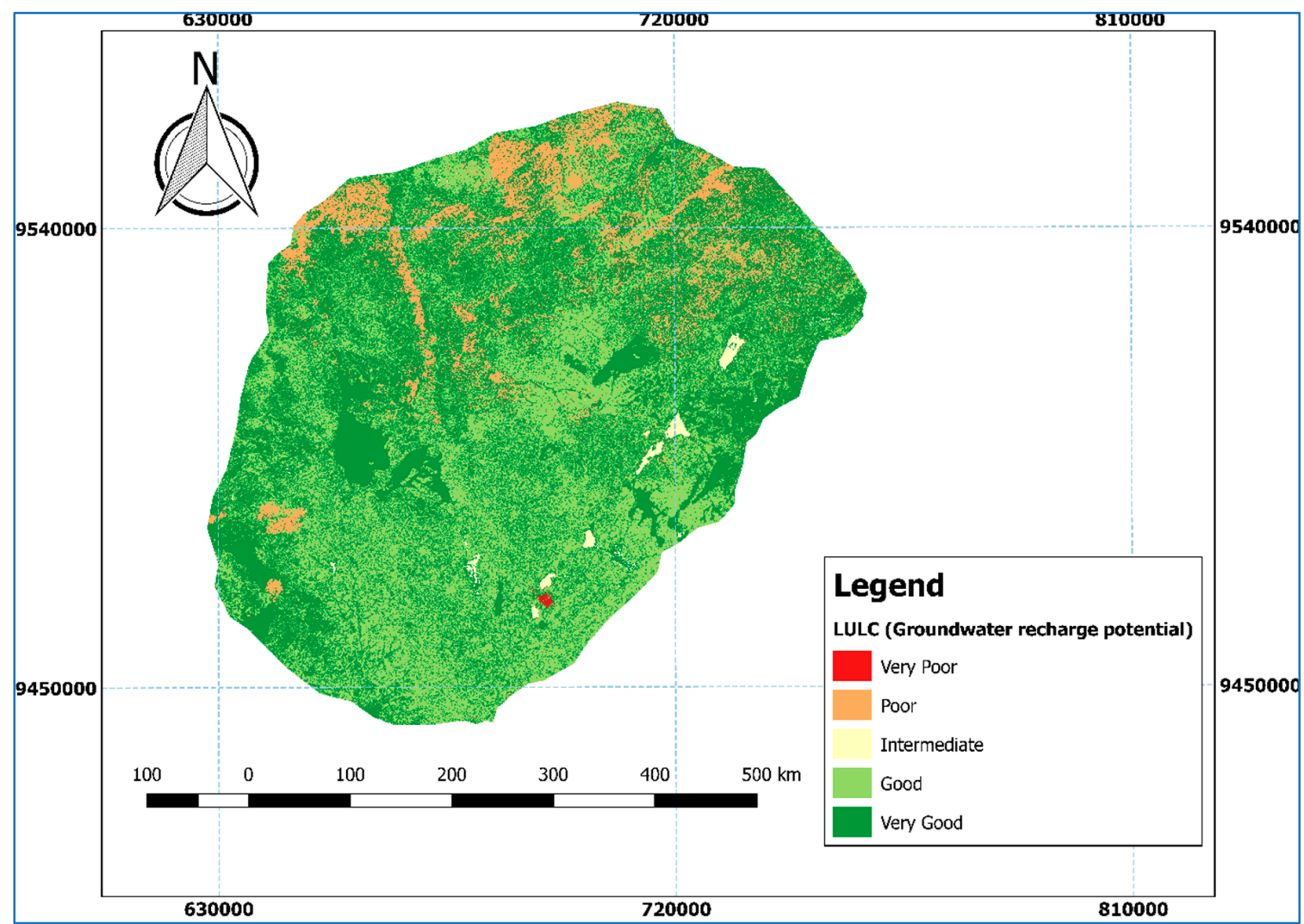

Figure 19. Groundwater recharge potential of land cover classes (WGS 84/UTM Zone 36S: EPSG: 32736).

\section{Potential groundwater recharge zones}

The study area has been delineated into five distinct groundwater potential recharge zones with very good, good, intermediate, poor and very poor groundwater recharge potential. A visual interpretation of the groundwater recharge potential map (Figure 20) indicates that the area which is suitably good for groundwater recharge is relatively small compared to the area which is poor to very poor. Notably, the area that is good, which is the second potentially excellent for groundwater recharge is relatively bigger than the area designated very good. However, the two areas are highly influenced by the distribution of lineaments, and thus have high lineament density.

Very good groundwater recharge potential areas have been observed in the northern-eastern, eastern to central parts of the study area while the north-western part is covered by areas with poor groundwater recharge potential. This is due to high slope, poor distribution of lineaments, high distribution of rock outcrops, especially in the north-western part of the study area. On the other hand, north-eastern, eastern and central parts of the study area are covered by high groundwater recharge potential areas due to the presence of high lineament density, and are mostly cultivated areas with patches of unconsolidated geological materials (sandy in the central part and volcanic in the north-eastern part). Therefore, very good to good recharge areas identified in the study area correspond to highly fractured zones, with high lineament density, which match with the gentle slope and unconsolidated tertiary to quaternary geological materials.

The combination of unconsolidated geological materials, land use/cover and lineament density has shown to influence the areas that are very good groundwater recharge zones. In this study, the impact of built-up areas on negatively affecting recharge has been masked by the distribution of lineaments, and albeit, the built-up area is relatively very small as compared to other land cover/use types with high influence on groundwater recharge. This is a vivid evidence that in consolidated fractured aquifers, secondary porosity dictates recharge to a great extent. Therefore, the movement and occurrence of groundwater in the study area very much depends on the secondary porosity and 
permeability resulting from faulting and fracturing. Thus, the most obvious hydrogeological features that are important from the groundwater and hydrogeology points of view are the lineaments.

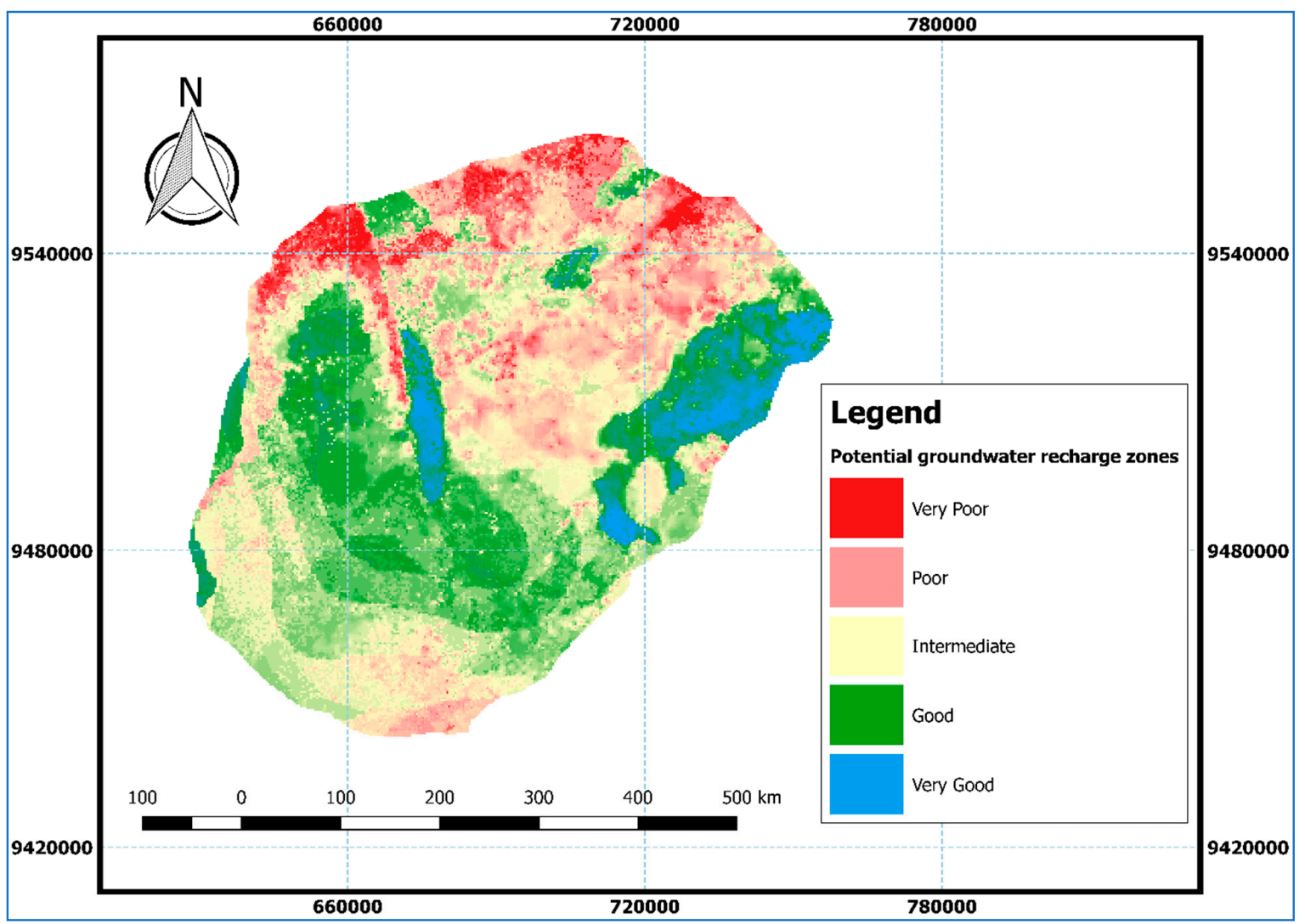

Figure 20. The groundwater recharge potential map of the Singida semi-arid fractured basement aquifer (WGS 84/UTM Zone 36S: EPSG: 32736).

Generally, the eastern and central parts are very good recharge areas, while the northern and western parts have exhibited very poor characteristics as groundwater recharge zones. The resulting map (Figure 20) gives an idea of where possibly recharge of the two important wellfields in Singida municipality, the Irao and Mwankoko comes from. The wellfields are within the crystalline, cratonic basement aquifer, receiving a maximum of $700 \mathrm{~mm}$ per year in a good year. This map can as well be used as a groundwater potential suitability map.

In addition to the designation of the study area into groundwater recharge potential areas, this study has also developed an equation for hydrogeological delineation of potential groundwater recharge areas (Equation (7)) in semi-arid fractured aquifers. The equation is a numerical indicator of the relative importance of the factors used in the hydrogeological delineation of groundwater recharge potential of the study area:

$$
\operatorname{Re}=0.21 \mathrm{~L}_{\mathrm{d}}+0.17 \mathrm{~L}_{\mathrm{t}}+0.15 \mathrm{~L}_{\mathrm{u}}+0.15 \mathrm{~S}_{\mathrm{o}}+0.13 \mathrm{R}_{\mathrm{f}}+0.11 \mathrm{~S}_{\mathrm{L}}+0.08 \mathrm{D}_{\mathrm{d}}
$$

where $\mathrm{L}_{\mathrm{d}}$ is lineament density, $\mathrm{L}_{\mathrm{t}}$ is Lithology/Hydrogeology, $\mathrm{Lu}$ is Land cover/use, $\mathrm{S}_{\mathrm{o}}$ is Soil, $\mathrm{R}_{\mathrm{f}}$ is Rainfall, $S_{L}$ is Slope and $D_{d}$ is Drainage density. $R_{e}$ is the overall groundwater recharge potential

This equation combines all the seven weighted factors. In this equation, lineament density carries $21 \%$, lithology/hydrogeology (17\%), land cover/use $(15 \%)$, soil $(15 \%)$, rainfall $(13 \%)$, slope $(11 \%)$ and drainage density ( $8 \%)$. 


\section{Discussion}

Delineation of potential groundwater recharge zones of the Singida, semi-arid basement aquifer has been carried out using open source QGIS software with its inherent plugins and algorithms. The results demonstrate that the use of remote sensing and GIS provide potentially powerful tools to study groundwater resources as reported previously by other researchers [21]. These tools can as well be used for groundwater exploration in the complex basement aquifers like the study area as supported by previous studies [19].

The combination of Ordered Weighted Averaging, SAGA, GRASS and Raster calculator algorithms have been instrumental for accomplishing the hydrogeological delineation of potential groundwater recharge zones. This approach has equally proven useful just like the commercial software for carrying out weighted overlay analysis despite the earlier claimed limitations of QGIS in carrying out weighted overlay analysis. This has also been reported by other researchers [21]. This is possibly one of the reasons as to why most of the recent and previous studies of this nature [15,17-20] utilized ArcGIS software and its inherent tools (e.g., spatial analyst) for carrying out weighted overlay analysis. This study has enabled an evaluation of the capabilities of QGIS and its inherent tools and algorithms in, not only carrying out weighted overlay analysis, but a comprehensive understanding of the potential groundwater recharge zones in a crystalline basement and highly fractured semi-arid area. Therefore, this study serves as a methodological breakthrough in terms of weighted overlay methodological approach and the use of open-source remote sensing and GIS software.

An overall perspective is that lineaments, lithology, land use/cover pattern, slope and the soil type play an important role in influencing groundwater recharge. Recent studies [21] concluded that lithology is the main controlling factor for groundwater recharge. These findings are supported by the results of this study but with a little improvement. In this study, it was found that lineament density and hydrogeology are the first and second most important controlling factors respectively. The deviation from the findings of a recent study [21] is due to the fact that the findings from that study [21] emanate from a basaltic geological environment while this study was carried out in a consolidated, fractured crystalline basement aquifer with patches of unconsolidated geological materials, covering less than $20 \%$ of the study area. The geological difference between the two study areas can be attributed to the diverging conclusions with regard to the factors that control groundwater recharge.

Areas and locations with very good groundwater recharge potential in the study area are relatively small in size as compared to areas that are designated as poor recharge zones. The potentially good groundwater recharge areas are predominantly characterized by a good distribution of the lineaments and the overlying land covers favor low runoff and high-water infiltration. Drainage density, soil texture, slope and rainfall are some of the less important factors in the study area. This observation has also been supported by other researchers $[19,41]$.

Lineament density in the study area has played an important role in revealing the potential groundwater recharge zones and locations. It particularly provided important information on subsurface fractures which act as conduits and thus control the movement and storage of groundwater. Generally, high potential recharge zones and locations in the Singida, semi-arid fractured aquifer match with high lineament density areas, cultivated and grassland areas, gently sloping areas, soils with sandy texture. Some of these factors result in low runoff potential and high infiltration. Low potential recharge areas correspond to structural hills, steep slopes, soils with clayey texture which facilitate high runoff and low infiltration as opined by previous researchers [20].

The presence of lineaments usually symbolizes a permeable zone through secondary porosity $[19,20]$. Moreover, other previous studies [19] reported that land use/cover and geology are said to be highly influential in determining potential groundwater recharge zones of an area while lineaments and soil are the least influential. The findings by these previous researchers [19] are very general in a sense that they do not consider the variation in geological and climatic conditions of different groundwater basins. Further to that, some studies [20] ignore the influence of lineaments in areas that are highly fractured with consolidated geological materials. However, some researchers [18] 
further argued that lineaments and land use are the most influential factors while soil and slope are least influential. In this study, it has been found that cultivated and grassland areas also favor high groundwater recharge potential. This is in line with the findings of other studies [21]. In addition to that, the built-up areas and forested land which are in the steep slope areas with massive rock outcrops in the north-western side of the study area have proven to be poor in influencing factors to groundwater recharge. This is contrary to the findings of previous studies [19] which found out that forested land is good at influencing groundwater recharge.

Moreover, the findings of this study are in line with those of previous studies [7,8,42-44], that in dry regions with high permeability terrains, regional groundwater flow makes up to $60 \%$ of the watershed budget. In this study, this implies that more recharge takes place far away from where the aquifers in semi-arid areas are (i.e., there is limited local recharge in the study area). This concretizes the argument that there is more regional to intermediate flows than local flows in semi-arid and arid regions. It has also been proven that in fractured aquifers, lineaments are hydrogeologically important structures as supported by previous authors $[45,46]$.

Owing to its semi-arid climatic condition, recharge potential of rainfall is very low. This is because most of the meteoric water in semi-arid areas is discharged through evapotranspiration and runoff as reported by other studies in semi-arid areas [47,48]. It has been also observed from the findings of previous studies [20,32], in sedimentary humid groundwater basins, rainfall, lithology and land use are the most important factors in determining groundwater recharge potential while lineament density is the least important parameter. Contrary to that, the findings of this study, together with the results reported by previous researchers $[17-19,26,46,48]$ have revealed that lineament density, lithology and land cover/use are the three most important factors in determining groundwater recharge potential in semi-arid, fractured groundwater basins while drainage density, rainfall and slope are the least important factors.

This study developed a groundwater recharge equation after combining 7 geological, topographic and climatic factors to delineate groundwater recharge potential zones (Equation (7)). The equation has been benchmarked by the other groundwater recharge potential equations developed by other researchers combining different geological, climatological and topographic factors as shown in Equation (8) to Equation (15), which have been reported by previous studies [17-20,26,32,46-48] in that order. They emanated from fractured semi-arid groundwater basins to humid, unconsolidated sedimentary aquifers:

$$
\begin{gathered}
\operatorname{Re}=0.2 \mathrm{G}_{\mathrm{w}}+0.15 \mathrm{~L}_{\mathrm{t}}+0.12 \mathrm{G}_{\mathrm{m}}+0.12 \mathrm{~L}_{\mathrm{d}}+0.12 \mathrm{~L}_{\mathrm{u}}+0.1 \mathrm{~S}_{\mathrm{L}}+0.1 \mathrm{~S}_{\mathrm{o}}+0.09 \mathrm{R}_{\mathrm{f}} \\
\operatorname{Re}=0.29 \mathrm{~L}_{\mathrm{u}}+0.28 \mathrm{~L}_{\mathrm{t}}+0.16 \mathrm{~S}_{\mathrm{L}}+0.13 \mathrm{G}_{\mathrm{m}}+0.12 \mathrm{~L}_{\mathrm{d}}+0.1 \mathrm{Dd}+0.03 \mathrm{~S}_{\mathrm{o}} \\
\operatorname{Re}=0.24 \mathrm{~L}_{\mathrm{u}}+0.23 \mathrm{~L}_{\mathrm{t}}+0.15 \mathrm{~S}_{\mathrm{L}}+0.12 \mathrm{~L}_{\mathrm{d}}+0.11 \mathrm{G}_{\mathrm{m}}+0.09 \mathrm{D}_{\mathrm{d}}+0.06 \mathrm{~S}_{\mathrm{o}} \\
\operatorname{Re}=0.18 \mathrm{~L}_{\mathrm{t}}+0.16 \mathrm{G}_{\mathrm{m}}+0.16 \mathrm{~L}_{\mathrm{u}}+0.14 \mathrm{~S}_{\mathrm{L}}+0.11 \mathrm{D}_{\mathrm{d}}+0.09 \mathrm{~L}_{\mathrm{d}}+0.09 \mathrm{R}_{\mathrm{f}} \\
\operatorname{Re}=0.38 \mathrm{~L}_{\mathrm{t}}+0.24 \mathrm{~L}_{\mathrm{d}}+0.16 \mathrm{G}_{\mathrm{m}}+0.1 \mathrm{~S}_{\mathrm{L}}+0.06 \mathrm{D}_{\mathrm{d}}+0.04 \mathrm{R}_{\mathrm{f}}+0.02 \mathrm{~L}_{\mathrm{u}} \\
\operatorname{Re}=0.18 \mathrm{~L}_{\mathrm{t}}+0.17 \mathrm{R}_{\mathrm{f}}+0.15 \mathrm{~S}_{\mathrm{o}}+0.13 \mathrm{G}_{\mathrm{m}}+0.13 \mathrm{~L}_{\mathrm{u}}+0.1 \mathrm{~S}_{\mathrm{L}}+0.08 \mathrm{~L}_{\mathrm{d}}+0.04 \mathrm{D}_{\mathrm{d}}+0.02 \mathrm{D}_{\mathrm{p}} \\
\operatorname{Re}=0.25 \mathrm{~L}_{\mathrm{t}}+0.25 \mathrm{G}_{\mathrm{m}}+0.15 \mathrm{~S}_{\mathrm{o}}+0.15 \mathrm{~L}_{\mathrm{u}}+0.1 \mathrm{~S}_{\mathrm{L}}+0.1 \mathrm{D}_{\mathrm{d}} \\
\operatorname{Re}=0.38 \mathrm{~L}_{\mathrm{t}}+0.24 \mathrm{~L}_{\mathrm{u}}+0.16 \mathrm{~L}_{\mathrm{d}}+0.1 \mathrm{~T}_{\mathrm{p}}+0.06 \mathrm{~S}_{\mathrm{L}}+0.04 \mathrm{D}_{\mathrm{d}}+0.02 \mathrm{R}_{\mathrm{f}}
\end{gathered}
$$

The equations in general revealed that land use, lithology and lineament density are the most important factors in fractured consolidated aquifers while in humid areas, rainfall, land use and geology are the most important factors. Equations derived from fractured consolidated basins compare very well with the findings of this study. 


\section{Conclusions}

The attempt to delineate and map potential groundwater recharge zones of the Singida, semi-arid, fractured crystalline basement aquifer using open source remote sensing and GIS software has been carried out. It has been demonstrated that a combination of hydrological, topographic, climatological and geological factors can determine how effective an area can be a potential recharge zone. The study has revealed that groundwater recharge areas for the Singida semi-arid fractured aquifer are restricted to areas with high lineament density, cultivated areas, grassland and flat to gentle slopes. Moreover, the potential of groundwater recharge is also observed in areas with low drainage density, although this is not a key determinant in the study area as revealed in the overall groundwater recharge potential map and the numerical equation. Generally, lineament density has been observed to dominate in locations and areas with high groundwater recharge potential. Although soil characteristics have been used in most previous works as an input factor for determining groundwater recharge potential of an area, in this study it has had limited contribution in delineating potential groundwater recharge areas.

The areas marked good and very good are recommended for artificial recharging structures as an alternative technique for enhancing groundwater recharge through rainwater harvesting to augment groundwater storage in this semi-arid, fractured crystalline basement aquifer. Given the low amount of rainfall as well as the increasing water demand in the study area, practitioners and decision makers can use the developed map for planning purposes in terms of groundwater replenishment by creating a preferential flow to the deep aquifers in the study area during the rainfall season. The knowledge and understanding of the potential recharge zones in the Singida semi-arid, fractured crystalline basement aquifer serves as a starting point for recharge zone protection.

The results are particularly important for monitoring and management of the Singida aquifer which is possibly and very likely fed by regional and sub-regional groundwater flow systems. This is due to its dry climate and limited amount of rainfall received annually which limits local recharge. The results also provide tentative but key information to practitioners (e.g., basin water officers and hydrogeologists) and high-level policy and decision makers on where regional and sub-regional flows for the two important wellfields in Singida municipality (Irao and Mwankoko) could be coming from. This information serves for recharge zone protection and management.

Open-source remote-sensing and GIS techniques used in this study have proven effective tools in delineating groundwater recharge zones and locations. Thus, this approach is recommended to complement geophysical and other groundwater exploration surveys, including geochemical and isotopic approaches. Researchers, especially those familiar with QGIS software can utilize this blended approach for carrying out suitability analysis using the weighted overlay analysis approach.

Author Contributions: Conceptualization, K.R.M.; methodology, K.R.M. and I.C.M.; software, K.R.M.; validation, I.C.M., R.L.M.; formal analysis, K.R.M., I.C.M.; investigation, K.R.M.; resources, K.R.M., I.C.M., R.L.M.; data curation, K.R.M., I.C.M.; writing—original draft preparation, K.R.M.; writing—review and editing, I.C.M., R.L.M.; visualization, K.R.M. and I.C.M.; supervision, I.C.M., R.L.M. All authors have read and agreed to the published version of the manuscript.

Funding: The Research work from which this manuscript has been developed has been funded by the Water, Infrastructure and Sustainable Energy Futures (WISE FUTURES) Centre of Excellence based at the Nelson Mandela African Institution of Science and Technology (NM-AIST), Arusha-Tanzania.

Acknowledgments: The authors wish to acknowledge the support of Water, Infrastructure and Sustainable Energy Futures (WISE FUTURES) Centre of Excellence based at the Nelson Mandela African Institution of Science and Technology (NM-AIST), Arusha-Tanzania for the scholarship which catered for tuition fees, accommodation, meals and partial research support. Moreover, the support from the Department of Geography and Environmental Studies at the Sokoine University of Agriculture is highly acknowledged for shouldering part of the PhD research costs through purchase of instruments and partial financial support to complement field activities. In addition, we are highly indebted to staff of the Internal Drainage Basin (IDB) head office in Singida for their immense support and generosity during field works and data provision. The support from the then IDB hydrogeologist Jumanne Baraka and his entire hydrogeology and hydrology teams is unforgettably revered and highly valued. We equally acknowledge the support from the Singida Urban Water Supply and Sanitation Authority (SUWASA) 
for issuing permission to work and collect data in the Mwankoko and Irao wellfields. The warm reception from the Authority's Director during a courtesy visit was very fulfilling and intellectually rewarding.

Conflicts of Interest: Authors declare no conflict of interest with any organization, person or a group of people which may impart bias of any kind in this work.

\section{References}

1. Murthy, K.S.R. Ground water potential in a semi-arid region of Andhra Pradesh-A geographical information system approach. Int. J. Remote Sens. 2000, 21, 1867-1884. [CrossRef]

2. Gleeson, T.; Befus, K.M.; Jasechko, S.; Luijendijk, E.; Cardenas, M.B. The global volume and distribution of modern groundwater. Nat. Geosci. 2015, 9, 161-167. [CrossRef]

3. Hernández-Mora, N.; Llamas, R.; Cortina, L.M. Misconceptions in Aquifer Over-exploitation: Implications for Water Policy in Southern Europe. In Agricultural Use of Groundwater; Springer Science and Business Media LLC: Dordrecht, The Netherlands, 2001; Volume 17, pp. 107-126.

4. Siebert, S.; Burke, J.; Faures, J.M.; Frenken, K.; Hoogeveen, J.; Döll, P.; Portmann, F.T. Groundwater use for irrigation-A global inventory. Hydrol. Earth Syst. Sci. 2010, 14, 1863-1880. [CrossRef]

5. Konikow, L.F. Groundwater depletion in the United States (1900-2008). Sci. Investig. Rep. $2013,63$. [CrossRef]

6. Dakhlalla, A.O.; Parajuli, P.B.; Ouyang, Y.; Schmitz, D.W. Evaluating the impacts of crop rotations on groundwater storage and recharge in an agricultural watershed. Agric. Water Manag. 2016, 163, 332-343. [CrossRef]

7. Haitjema, H.; Mitchell-Bruker, S. Are Water Tables a Subdued Replica of the Topography? Ground Water 2005, 43, 781-786. [CrossRef]

8. Gleeson, T.; Marklund, L.; Manning, A.H.; Smith, L. Classifying the water table at regional to continental scales. Geophys. Res. Lett. 2011, 38, 1-6. [CrossRef]

9. Acharya, T.; Kumbhakar, S.; Prasad, R.; Mondal, S.; Biswas, A. Delineation of potential groundwater recharge zones in the coastal area of north-eastern India using geoinformatics. Sustain. Water Resour. Manag. 2017, 5 , 533-540. [CrossRef]

10. Palmer, P.C.; Gannett, M.; Hinkle, S.R. Isotopic characterization of three groundwater recharge sources and inferences for selected aquifers in the upper Klamath Basin of Oregon and California, USA. J. Hydrol. 2007, 336, 17-29. [CrossRef]

11. Yusuf, M.; Abiye, T.; Butler, M.; Ibrahim, K. Origin and residence time of shallow groundwater resources in Lagos coastal basin, south-west Nigeria: An isotopic approach. Heliyon 2018, 4, e00932. [CrossRef]

12. Bakari, S.S.; Aagaard, P.; Vogt, R.D.; Ruden, F.; Johansen, I.; Vuai, S.A. Delineation of groundwater provenance in a coastal aquifer using statistical and isotopic methods, Southeast Tanzania. Environ. Earth Sci. 2011, 66, 889-902. [CrossRef]

13. Tiwari, A.; Rai, B. Hydromorphogeological Mapping for Groundwater Prospecting Using Landsat-MSS Images-A Case Study of Part of Dhanbad District, Bihar. J. Indian Soc. Remote Sens. 1996, 24, 281-285. [CrossRef]

14. Srinivasan, P. Use of remote sensing techniques for detailed hydrogeological investigations in parts of Narmada Sagar command area, MP. J. Indian Soc. Remote Sens. 1988, 16, 55-62. [CrossRef]

15. Saraf, A.K.; Choudhary, E.R. Integrated remote sensing and GIS for ground water exploration and identification of artificial recharge sites. Int. J. Remote Sens. 1998, 19, 1825-1841. [CrossRef]

16. Rao, N.S.; Chakradhar, G.K.J.; Srinivas, V. Identification of Groundwater Potential Zones Using Remote Sensing Techniques in and Around Guntur Town, Andhra Pradesh, India. J. Indian Soc. Remote Sens. 2001, 29, 69-78. [CrossRef]

17. Samson, S.; Elangovan, K. Delineation of Groundwater Recharge Potential Zones in Namakkal District, Tamilnadu, India Using Remote Sensing and GIS. J. Indian Soc. Remote Sens. 2015, 43, 769-778. [CrossRef]

18. Selvam, S.; Dar, F.A.; Magesh, N.S.; Singaraja, C.; Venkatramanan, S.; Chung, S.Y. Application of remote sensing and GIS for delineating groundwater recharge potential zones of Kovilpatti Municipality, Tamil Nadu using IF technique. Earth Sci. Inform. 2015, 9, 137-150. [CrossRef] 
19. Raviraj, A.; Kuruppath, N.; Kannan, B. Identification of Potential Groundwater Recharge Zones Using Remote Sensing and Geographical Information System in Amaravathy Basin. J. Remote Sens. GIS 2017, 6, 1-10. [CrossRef]

20. Das, S.; Pardeshi, S.D. Integration of different influencing factors in GIS to delineate groundwater potential areas using IF and FR techniques: A study of Pravara basin, Maharashtra, India. Appl. Water Sci. 2018, 8, 197. [CrossRef]

21. Das, S.; Gupta, A.; Ghosh, S. Exploring groundwater potential zones using MIF technique in semi-arid region: A case study of Hingoli district, Maharashtra. Spat. Inf. Res. 2017, 25, 749-756. [CrossRef]

22. Hamilton, W.B. Archean magmatism and deformation were not products of plate tectonics. Precambrian Res. 1998, 91, 143-179. [CrossRef]

23. Stanley, S.M. Earth System History; W.H. Freeman and Company: New York, NY, USA, 1999; pp. $297-302$. ISBN 0-7167-2882-6.

24. Grotzinger, J.P.; Jordan, T.H. Understanding Earth, 6th ed.; W. H. Freeman: New York, NY, USA, 2010; ISBN 978-1429219518.

25. Petit, C. Continental hearts: Ancient expanses called cratons pose a geological puzzle. Sci. News 2010, 178, 22-26. [CrossRef]

26. Fenta, A.A.; Kifle, A.; Gebreyohannes, T.; Hailu, G. Spatial analysis of groundwater potential using remote sensing and GIS-based multi-criteria evaluation in Raya Valley, northern Ethiopia. Hydrogeol. J. 2014, 23, 195-206. [CrossRef]

27. Jaiswal, R.K.; Mukherjee, S.; Krishnamurthy, J.; Saxena, R. Role of remote sensing and GIS techniques for generation of groundwater prospect zones towards rural development-An approach. Int. J. Remote Sens. 2003, 24, 993-1008. [CrossRef]

28. Rao, Y.S.; Jugran, D.K. Delineation of groundwater potential zones and zones of groundwater quality suitable for domestic purposes using remote sensing and GIS. Hydrol. Sci. J. 2003, 48, 821-833. [CrossRef]

29. Sener, E.; Davraz, A.; Ozcelik, M. An integration of GIS and remote sensing in groundwater investigations: A case study in Burdur, Turkey. Hydrogeol. J. 2004, 13, 826-834. [CrossRef]

30. Chowdhury, A.; Jha, M.K.; Chowdary, V.M.; Mal, B.C. Integrated remote sensing and GIS-based approach for assessing groundwater potential in West Medinipur district, West Bengal, India. Int. J. Remote Sens. 2008, 30, 231-250. [CrossRef]

31. Hammouri, N.; El-Naqa, A.; Barakat, M. An Integrated Approach to Groundwater Exploration Using Remote Sensing and Geographic Information System. J. Water Resour. Prot. 2012, 4, 717-724. [CrossRef]

32. Fashae, O.; Tijani, M.; Talabi, A.O.; Adedeji, O.I. Delineation of groundwater potential zones in the crystalline basement terrain of SW-Nigeria: An integrated GIS and remote sensing approach. Appl. Water Sci. 2013, 4, 19-38. [CrossRef]

33. Ramu, M.B.; Vinay, M. Identification of groundwater potential zones using GIS and Remote Sensing Techniques: A case study of Mysore Taluk-Karnataka. Int. J. Geomat. Geosci. 2014, 5, 393-403.

34. Manikandan, J.; Kiruthika, A.M.; Sureshbabu, S. Evaluation of groundwater potential zones in Krishnagiri district, Tamil Nadu using MIF technique. Int. J. Innov. Res. Sci. 2014, 4, 70-88.

35. Bagyaraj, M.; Ramkumar, T.; Venkatramanan, S.; Gurugnanam, B.; Senapathi, V. Application of remote sensing and GIS analysis for identifying groundwater potential zone in parts of Kodaikanal Taluk, South India. Front. Earth Sci. 2012, 7, 65-75. [CrossRef]

36. Jenifer, M.A.; Jha, M.K. Comparison of Analytic Hierarchy Process, Catastrophe and Entropy techniques for evaluating groundwater prospect of hard-rock aquifer systems. J. Hydrol. 2017, 548, 605-624. [CrossRef]

37. Thomas, R.; Duraisamy, V. Hydrogeological delineation of groundwater vulnerability to droughts in semi-arid areas of western Ahmednagar district. Egypt. J. Remote Sens. Space Sci. 2018, 21, 121-137. [CrossRef]

38. Mehra, M.; Oinam, B.; Singh, C.K. Integrated Assessment of Groundwater for Agricultural Use in Mewat District of Haryana, India Using Geographical Information System (GIS). J. Indian Soc. Remote Sens. 2016, 44, 747-758. [CrossRef]

39. Mehra, M.; Singh, C.K. Spatial analysis of soil resources in the Mewat district in the semiarid regions of Haryana, India. Environ. Dev. Sustain. 2016, 20, 661-680. [CrossRef]

40. Singh, C.K.; Shashtri, S.; Singh, A.; Mukherjee, S. Quantitative modeling of groundwater in Satluj River basin of Rupnagar district of Punjab using remote sensing and geographic information system. Environ. Earth Sci. 2010, 62, 871-881. [CrossRef] 
41. Nag, S.K. Application of lineament density and hydrogeomorphology to delineate groundwater potential zones of Baghmundi block in Purulia District, West Bengal. J. Indian Soc. Remote Sens. 2005, 33, 521-529. [CrossRef]

42. Dar, I.A.; Sankar, K.; Dar, M.A. Remote sensing technology and geographic information system modeling: An integrated approach towards the mapping of groundwater potential zones in Hardrock terrain, Mamundiyar basin. J. Hydrol. 2010, 394, 285-295. [CrossRef]

43. Rajaveni, S.P.; Brindha, K.; Elango, L. Geological and geomorphological controls on groundwater occurrence in a hard rock region. Appl. Water Sci. 2015, 7, 1377-1389. [CrossRef]

44. Machiwal, D.; Jha, M.K.; Mal, B.C. Assessment of Groundwater Potential in a Semi-Arid Region of India Using Remote Sensing, GIS and MCDM Techniques. Water Resour. Manag. 2010, 25, 1359-1386. [CrossRef]

45. Solomon, S.; Quiel, F. Groundwater study using remote sensing and geographic information systems (GIS) in the central highlands of Eritrea. Hydrogeol. J. 2006, 14, 1029-1041. [CrossRef]

46. Savita, R.; Mittal, H.; Satishkumar, U.; Singh, P.; Yadav, K.K.; Jain, H.; Mathur, S.; Davande, S. Delineation of Groundwater Potential Zones using Remote Sensing and GIS Techniques in Kanakanala Reservoir Subwatershed, Karnataka. Int. J. Curr. Microbiol. Appl. Sci. 2018, 7, 273-288. [CrossRef]

47. Maurice, L.; Taylor, R.G.; Tindimugaya, C.; Macdonald, A.; Johnson, P.; Kaponda, A.; Owor, M.; Sanga, H.; Bonsor, H.C.; Darling, W.G.; et al. Characteristics of high-intensity groundwater abstractions from weathered crystalline bedrock aquifers in East Africa. Hydrogeol. J. 2018, 27, 459-474. [CrossRef]

48. Hernandez-Marin, M.; Guerrero-Martínez, L.; Zermeño-Villalobos, A.; Rodríguez-González, L.; Burbey, T.J.; Pacheco-Martinez, J.; Martínez-Martínez, S.I.; González-Cervantes, N. Spatial and temporal variation of natural recharge in the semi-arid valley of Aguascalientes, Mexico. Hydrogeol. J. 2018, 26, 2811-2826. [CrossRef]

(C) 2020 by the authors. Licensee MDPI, Basel, Switzerland. This article is an open access article distributed under the terms and conditions of the Creative Commons Attribution (CC BY) license (http://creativecommons.org/licenses/by/4.0/). 